Published in final edited form as:

Nano Today. 2015 August 1; 10(4): 451-467. doi:10.1016/j.nantod.2015.06.004.

\title{
Photoresponsive nanoparticles for drug delivery
}

\author{
Alina Y. Rwei ${ }^{\mathrm{a}, \mathrm{b}, 1}$, Weiping Wang ${ }^{\mathrm{a}, \mathrm{c}, 1}$, and Daniel S. Kohane ${ }^{\mathrm{a}, \mathrm{c},{ }^{*}}$ \\ aLaboratory for Biomaterials and Drug Delivery, Department of Anesthesiology, Boston Children's \\ Hospital, Harvard Medical School, Boston, MA 02115, USA \\ bDepartment of Materials Science and Engineering, Massachusetts Institute of Technology, \\ Cambridge, MA 02139, USA \\ 'David H. Koch Institutes for Integrative Cancer Research, Massachusetts Institute of \\ Technology, Cambridge, MA 02139, USA
}

\section{Summary}

\begin{abstract}
Externally triggerable drug delivery systems provide a strategy for the delivery of therapeutic agents preferentially to a target site, presenting the ability to enhance therapeutic efficacy while reducing side effects. Light is a versatile and easily tuned external stimulus that can provide spatiotemporal control. Here we will review the use of nanoparticles in which light triggers drug release or induces particle binding to tissues (phototargeting).
\end{abstract}

\section{Introduction}

The efficacy and toxicity of drugs depend not only on their potency and other pharmacodynamic parameters but also on their ability to get to their target sites in preference to non-target tissues, i.e. pharmacokinetics. With conventional systemic drug administration methods, it is difficult to control the distribution of therapeutic agents. Consequently, drugs commonly have side effects. Conventional methods also are poorly suited to maintaining effective drug concentrations at target sites over extended periods, which necessitates multiple administrations [1].

Nanoparticles offer many advantages as therapeutic carriers, including the potential to increase drug circulation time, enhance drug solubility, deliver preferentially to target sites, and decrease side effects [2-4]. Nanoencapsulation allows drugs with poor solubility in blood to be delivered through the bloodstream [5] and protects their therapeutic payloads from the environment [6]. Nanoparticles with sizes between $\sim 30 \mathrm{~nm}$ and $200 \mathrm{~nm}$ accumulate preferentially in tissues with relatively leaky vasculatures, such as in tumors, an effect known as enhanced permeation and retention (EPR) [7]. This can lead to an enhancement of

\footnotetext{
"Corresponding author at: Laboratory for Biomaterials and Drug Delivery, Department of Anesthesiology, Boston Children's Hospital, Harvard Medical School, Boston, MA 02115, USA. Tel.: +1 617919 2364. daniel.kohane@ childrens.harvard.edu (D.S. Kohane).

${ }^{1}$ Both authors contributed equally to this work.

Publisher's Disclaimer: This is a PDF file of an unedited manuscript that has been accepted for publication. As a service to our customers we are providing this early version of the manuscript. The manuscript will undergo copyediting, typesetting, and review of the resulting proof before it is published in its final citable form. Please note that during the production process errors may be discovered which could affect the content, and all legal disclaimers that apply to the journal pertain.
} 
therapeutic effect. Preferential targeting of tissues using nanoparticles can be enhanced by "active targeting", i.e. by attachment of ligands which target the tissue of interest, by application of an external energy source, or other means. To date, over two dozen nanomedicine products have been approved for clinical use, and more are currently in clinical trials [8]. However, commercially available nanomedicines provide, at best, passive drug targeting or release. Their drug release profiles tend to be fixed, irrespective of changing patient needs and/or physiological conditions. Better spatial and temporal control would enhance efficacy (drug release at the desired site), and minimize toxicity by reducing drug release at off-target sites. Moreover, such control would allow release kinetics to be adjusted by the patient or by healthcare providers to match changing needs.

Externally triggerable drug delivery vehicles have been developed to address these considerations $[9,10]$. A wide range of energy sources can be used as triggering agents, such as ultrasound [11], magnetic fields [12], and light [13]. Light itself already has therapeutic uses. For example, photodynamic therapy (PDT) utilizes light to generate cytotoxic agents (reactive oxygen species) that can eliminate the neovasculature in angiogenesis [14], and is used to treat age-related macular degeneration (AMD) and cancers. Photocoagulation uses light to heat tissues and coagulate leaking blood vessels for the treatment of ocular diseases such as diabetic retinopathy [15]. Light has gained much interest as an external stimulus for drug targeting and release because of its clinical relevance and excellent spatiotemporal controllability.

While light has been used to trigger drug delivery devices of a wide range of sizes [13, 1620], this article will focus on developments in nanoparticulate photoresponsive drug delivery systems, including phototriggered targeting of and drug release from nanoparticles. We will first discuss some considerations relevant to the clinical application of light, including its ability to penetrate tissues and the resulting toxicities. We will familiarize readers with basic principles of photoresponsive mechanisms, and then provide examples of photoresponsive nanoparticles in which they have been employed. We will conclude with an analysis of the opportunities and challenges in the field of photoresponsive nanoparticles for drug delivery.

\section{Clinical considerations of light}

The effectiveness of light-triggerable drug delivery systems depends on the properties of the vehicle and the drug, as well as of the properties of the external light (wavelength and power) used, which will affect the depth to which the light will penetrate and the resulting tissue toxicity.

\section{Light penetration}

Light interacts with tissues through two major pathways: scattering and absorption. Scattering of a photon occurs because of fluctuations in a tissue's refractive index, resulting in a change of propagation direction [21]. Absorption occurs when the energy of the irradiating photon matches the energy difference between a molecule's ground state and excited states [22]. Scattering and absorption attenuate the irradiance (i.e., surface power density) of the propagated light exponentially with distance [22]. The theory governing tissue penetration by light is reviewed in detail elsewhere [23, 24]. A rule of thumb is that 
the penetration depth of light is inversely proportional to the attenuation coefficient, which is a positive function of the absorption coefficient and the scattering coefficient, both dependent on irradiation wavelength and the type of tissue [25-27].

The major tissue chromophores, including hemoglobin, myoglobin and melanin, have strong absorption in the UV and visible light range, resulting in low penetration depth of light of those wavelengths $[21,22,24,28]$. Tissue penetration is also poor at $>900 \mathrm{~nm}$, due to light absorption by water [26]. An absorption minimum is observed at NIR wavelengths (650 nm $-900 \mathrm{~nm}$ ), also known as the NIR window (Figure 1) [29]. Consequently, there is relatively high transmittance of NIR light in tissue [30]. In the NIR window, light can penetrate as deeply as the centimeter scale. The penetration depth of visible light is much shorter and decreases as the wavelength decreases to the UV range [22,23]. The relatively deep penetration of NIR light makes it a desirable tool for the activation of drug delivery vehicles in living systems.

\section{Phototoxicity}

Phototoxicity to tissues depends on the energy of photons (wavelength) and the irradiance employed. The energy of light is governed by the Planck-Einstein relation:

$$
\mathrm{E}=\frac{\mathrm{hc}}{\lambda}
$$

where:

$$
\begin{aligned}
& \mathrm{E}=\text { Energy of a photon } \\
& \mathrm{h}=\text { Planck's constant } \\
& \mathrm{c}=\text { Speed of light } \\
& \lambda=\text { Wavelength of light. }
\end{aligned}
$$

There is an inverse relationship between photon energy and the wavelength of light, which is why photons of shorter wavelengths have sufficient energy to break covalent bonds but those with longer wavelengths often do not.

As light propagates through tissues, the absorbed optical energy excites tissue chromophores, which eventually relax to their ground state by re-emitting another photon (fluorescence or phosphorescence), driving a chemical reaction (photochemical reaction), or converting the energy to heat (photothermal effect) [22]. Phototoxicity can be induced by the latter two processes [22].

Photosensitization is an example of a photochemical reaction: light-absorbing chromophores can generate free radicals when excited, resulting in protein denaturation [31,32], DNA breakage [33], or lipid peroxidation [15], which destabilizes the cells and results in cell death. Photomechanical damage is a photochemical effect that occurs when an ultrafast high-energy pulsed laser is utilized [21]. The focused laser pulses generate an electric field sufficient to ionize the irradiated tissue, producing an expanding plasma (an ionized volume with high density of free electrons) that causes a sudden increase in temperature and 
pressure, generating shockwaves that mechanically disrupt the tissue and forming vapor microbubbles [22, 34]. Such mechanical stress can cause cell death $[35,36]$.

Photothermal toxicity occurs when the rate of energy delivery exceeds the rate of energy dissipation in tissues [15]. Increasing temperature induces cytotoxic effects by protein denaturation and/or by an increase in cell membrane lipid fluidity. Cells undergo apoptosis at temperatures greater than $\sim 57^{\circ} \mathrm{C}-59^{\circ} \mathrm{C}$; necrosis occurs at temperatures above $60{ }^{\circ} \mathrm{C}$; and cells die immediately from heat fixation as temperatures exceed $72{ }^{\circ} \mathrm{C}$ [37].

It is important to differentiate between bulk heating of tissues by irradiation and the heating of nanoparticles within that tissue by, for example, the plasmonic photothermal effect (see below). The temperature required to trigger an effect on the surface of the nanoparticles does not necessarily become the temperature throughout the surrounding tissues, i.e. drug delivery can be triggered within tissues by the photothermal effect without resulting in thermal injury to tissues [13].

The American National Standards Institute (ANSI) has guidelines for the maximum permissible exposure (MPE) to lasers and light-emitting diodes (LEDs), based on ocular irradiation $[38,39]$. The maximal power flux allowed differs for each wavelength. In general, phototoxicity is lower at the longer wavelengths of visible light and in the NIR window wavelengths, where tissue absorption is relatively low [40]. The MPE is also dependent on irradiation time; the longer the duration of irradiation the lower the MPE allowed. For example, with light exposures shorter than $1 \mathrm{~s}$, the MPE of $700 \mathrm{~nm}$ noncollimated lasers (such as laser arrays or multiple diode lasers) is $10 \mathrm{~W} / \mathrm{cm}^{2} \bullet$ steradian (sr), but with exposures of $10 \mathrm{~min}$, the MPE drops to $0.4 \mathrm{~W} / \mathrm{cm}^{2} \bullet$ sr [38]. For ultrafast-pulsed lasers, the MPE is dependent on additional factors such as pulse duration and pulse interval. It is therefore important that the details (irradiance, wavelength, duration, etc.) be clearly presented in scientific publications. In general, UV light has a higher energy per photon and higher tissue absorbance, thus a lower MPE. NIR has lower energy per photon and lower tissue absorbance, thus a higher MPE.

\section{Mechanisms of photoresponsiveness}

Mechanisms used for phototriggered drug delivery have in common that materials absorb electromagnetic radiation and convert it to various forms of energy (Figure 2a) [41-43]. The photoresponsiveness of a particle is dependent on its absorption cross section (a measure of the probability of photon absorbance by each particle) and quantum yield (number of events per absorbed photon by each particle, where "events" can be chemical reactions or photons released) [44]. The product of the absorption cross section and quantum yield determines the efficiency of this energy conversion process.

\section{Direct action of UV/visible light}

A single UV/visible photon possesses sufficient energy to achieve photochemical reactions that have been widely used as the basis for photoresponsive nanoparticles (Figure 2b). For example, such light can make photochromic groups (i.e. groups that can transit reversibly between two structures when irradiated) such as azobenzenes and spiropyran transform 
reversibly between their isomers (photoisomerization), resulting in a change in polarity and hydrophobicity that can lead to the organization or disassembly of nanoparticles [41, 45]. UV/visible light can also irreversibly cleave chemical groups (called photocleavable/ photoremovable/photolabile groups) such as $o$-nitrobenzyl- and coumarin-based groups. The chemistry of photocleavable groups has been reviewed in detail [44, 46, 47]. Photocleavage reactions are often used to affect factors that maintain particle integrity, such as the hydrophilic-hydrophobic balance and the stability of polymer building blocks, to cleave linkages between drug molecules and nanoparticles, or to remove moieties that prevent particle binding ("caging" groups) $[41,42,48]$. Light can induce rearrangement reactions as well. The hydrophobic 2-diazo-1,2-naphthoquinone (DNQ) group can undergo a UVinduced Wolff rearrangement to form a hydrophilic 3-indenecarboxylic acid group [49]. This hydrophobicity change has been used to disrupt nanoparticles containing DNQ [48, 50]. In addition, light can cause inter-molecular crosslinking (photocrosslinking), such as the $[2+2]$ photocycloaddition of coumarin groups, to induce shrinking of nanostructures or disruption of the uniform packaging of building blocks, causing drug release [42, 50, 51].

\section{Conversion of NIR light to UV/visible light}

Photochemical reactions require high-energy light, limiting them to the UV/visible wavelengths, which penetrate tissues poorly and may induce tissue injury. While NIR light has many desirable properties, its energy is often too low to cause photoresponsive chemical reactions. Recently, efforts to combine the tissue penetration seen with NIR with the ability to achieve chemical reactions of lower wavelengths have employed strategies to upconvert photon energy from the NIR wavelengths to UV/visible wavelengths. One of these strategies is the two-photon absorption process, where photosensitive groups, such as $o$-nitrobenzyland coumarin-derivatives, simultaneously absorb two photons of NIR light to achieve a chemical reaction as if absorbing one photon of UV/visible light [44, 52]. The probability of excitation by two-photon absorption is generally low and proportional to the square of the intensity of the incident light [53], resulting in a need for pulsed lasers with high power densities. Such lasers have a very small field of use (millimeters), limiting their clinical application. Another way to achieve the upconversion of light is to use upconverting nanoparticles (usually lanthanide-based nanomaterials) to convert NIR light to UV/visible light [54-56]. Upconverting nanoparticles can be used with continuous wave (CW) lasers which have relatively low power densities. Upconverting nanoparticles are relatively resistant to photobleaching and photoblinking [53].

\section{Photosensitization-induced oxidation}

Strong oxidizing agents, such as singlet oxygen, can be generated inside drug delivery vehicles by irradiating incorporated photosensitizers with an appropriate wavelength of light. The generated oxidizing agents can be used to induce further chemical changes in the drug delivery system. For example, photosensitized singlet oxygen can disrupt liposomes by oxidizing lipids [42]. 


\section{Plasmonic effect}

Noble metal nanoparticles can be irradiated at certain wavelengths so that their free metal electrons collectively oscillate in-phase with the electric field of the incident light, a phenomenon known as surface plasmon resonance (SPR). Hence, such particles are often termed plasmonic nanoparticles. The wavelength at which SPR occurs is highly dependent on the particle geometry, as explained by Mie theory and later generalized by Gans for anisotropic nanostuctures $[57,58]$.

Plasmonic nanoparticles can efficiently convert photon energy into heat by SPR (photothermal effect), allowing the disruption of non-covalent interactions, e.g., dehybridization of nucleic acids, and collapse of thermoresponsive polymers. When plasmonic nanoparticles are irradiated with high energy ultrafast pulsed lasers, transient cavitation of vapor microbubbles are commonly induced due to the high temperature gradient between the nanoparticles and the surrounding medium [59, 60]. Apart from photothermal conversion, gold nanoparticles have been shown to induce photochemical reactions, presumably because light stimulates electrons of the nanoparticles to initiate goldthiol bond disassociation and release of covalently attached drugs [61].

\section{Drug release from photoresponsive nanoparticles}

Many types of nanoparticles have been used for drug delivery (Figure 3). Inorganic particles such as plasmonic and upconverting nanoparticles can deliver drugs that are covalently bound to their surfaces. Mesoporous silica nanoparticles encapsulate drugs within their porous structures. Organic vesicles such as liposomes and polymersomes are formed by selfassembly and have a hydrophilic core and hydrophobic bilayer, enabling them to deliver both hydrophobic and hydrophilic drugs. Polymeric micelles and solid organic nanoparticles predominantly deliver hydrophobic drugs within their hydrophobic cores, though covalently bound hydrophilic drugs can also be delivered. Nanogels are crosslinked structures of hydrophilic polymers that can physically entrap drugs (based on properties such as charge and size) or have them covalently attached to the polymers of which the gels are made. We will provide illustrative examples of several particle types and the ways in which they have been used with light. To the extent that is possible from the descriptions provided in the literature, we have specified the irradiation conditions (i.e. wavelength, power or irradiance, duration) that have been used.

\section{Plasmonic nanoparticles}

Plasmonic nanoparticles are relatively easy to make with defined geometries, which affect the wavelengths at which phototriggered effects are produced. Chemical functionalization is also straightforward, allowing the attachment of polymers, drugs, etc. The clinical relevance of plasmonic nanoparticles has grown as drug delivery systems based on the fact that gold nanoparticles have moved into clinical trials [62-64]. However, the phototriggerability of these drug delivery systems has not yet been applied in clinical settings.

The photothermal effect has been widely used to disrupt non-covalent interactions between drug and particle, resulting in the release of drug cargo [13, 65, 66]. For example, the photothermal effect can be used to trigger drug release by affecting the hydrophilic- 
hydrophobic balance of thermally responsive polymers associated with plasmonic nanoparticles. Most of these polymers undergo a volume phase transition at their lower critical solution temperature (LCST), below which the polymers are miscible in aqueous solutions, but above the LCST they become insoluble [67]. When thermo-responsive polymers are incorporated into nanoparticle systems, a temperature increase above LCST renders the polymers hydrophobic and induces the polymers to collapse, triggering the release of encapsulated drugs. One example of such a system is gold nanocages [65] that were covalently functionalized with a thermo-responsive polymer, poly $(\mathrm{N}-$ isopropylacrylamide-co-acrylicamide) (pNIPAAm-co-pAAm), with a LCST of $39{ }^{\circ} \mathrm{C}$ (Figure 4). At body temperature $\left(37^{\circ} \mathrm{C}\right)$, the polymers were in an extended conformation that sealed the pores in the nanocages, preventing dye release. At temperatures above LCST the polymers collapsed, allowing dyes to be released through the pores. When nanocages loaded with the chemotherapeutic drug doxorubicin were incubated with cancer cells, irradiation at NIR wavelengths $\left(730 \mathrm{~nm}-820 \mathrm{~nm}, 20 \mathrm{~mW} / \mathrm{cm}^{2}\right)$ for 2 min resulted in $>30 \%$ loss in cell viability.

The photothermal effect has also been used to release oligonucleic acids from plasmonic nanoparticles via thermal dehybridization [68-70]. Single-stranded DNA (ssDNA) was bound to complementary DNA sequences immobilized on gold nanoparticles [68]. Upon irradiation, particle heating by the photothermal effect led to the release of ssDNA. Irradiation (at $800 \mathrm{~nm}$, at $2.5 \mathrm{~W} / \mathrm{cm}^{2}$ for $2 \mathrm{~min}$ ) of those nanoparticles loaded with GFP antisense ssDNA caused a $47 \%$ downregulation of GFP expression in human lung cancer cells [69]. Irradiation-induced release of other molecules selectively bound to DNA was also demonstrated [70].

Irradiation of plasmonic particles can release drugs by mechanisms other than the SPR photothermal effect. Drugs were released upon irradiation by disrupting covalent gold-thiol bonds that attached them to the surface of gold nanoparticles [58]. In addition, irradiation of plasmonic nanoparticles can cause photoacoustic effects, leading to the formation of vapor microbubbles [59,60]. These microbubbles disrupt lipid membranes in liposomes, which can trigger drug release, and in endosomes, which can enhance endosomal escape [59, 7173]. As an example, siRNA was conjugated to hollow gold nanoshells with covalent Au-S bonds $[60,73]$. Endosomal escape and detachment of siRNA were both observed after irradiation with a femtosecond pulsed laser; the endosomal escape was attributed to membrane disruption by cavitation, and the release of siRNA to the breaking of Au-S bonds. Human epithelial prostate cancer cells (PPC-1) exposed to gold nanoshells carrying siRNA targeting the polo-like kinase (PLK1), a kinase expressed in prostate cancer cells [60], showed a 60-70\% decrease in PLK1 expression upon irradiation ( $\left.800 \mathrm{~nm}, 2.4 \mathrm{~W} / \mathrm{cm}^{2}, 10 \mathrm{~s}\right)$.

\section{Liposomes}

Liposomes are micro- to nano-scale vesicles that have an aqueous core encapsulated within lipid bilayers [74]. Hydrophilic drugs can be encapsulated in the aqueous core, and hydrophobic compounds can be loaded into the lipid bilayer. Many liposomal formulations have been FDA-approved and more are currently undergoing clinical trials [75, 76]. Light has been used in the clinical setting to activate photosensitizers contained within liposomes, 
e.g. for localized photodynamic therapy [77]. Drug release from liposomes can be triggered by a variety of photoresponsive mechanisms, including use of photosensitizers [78-80], photoisomerization [81-83], photopolymerization [84, 85], photothermal effects [59, 86-88] and others.

Drugs encapsulated in thermosensitive liposomes can be released by the photothermal effect of associated plasmonic nanoparticles. At physiological temperature, the liposome is stable and does not release cargo. As temperature increases above its phase transition temperature, melting of lipids occurs, and the fluidity of the lipid bilayer increases so as to release the encapsulated cargo. For example, gold nanoparticles were deposited by the reduction of gold ions onto the surface of liposomes that contained dipalmitoylphosphatidylcholine (DPPC). DPPC has a phase transition temperature of $41{ }^{\circ} \mathrm{C}$, and the liposomes released encapsulated drugs when the gold nanoparticles were heated above this phase transition temperature by NIR light irradiation at $760 \mathrm{~nm}$ (Figure 5) [88]. Activation of a G-protein-coupled receptor (GPCR) pathway was achieved in human embryonic kidney cells by triggering release of a ligand that binds to the GPCR from such liposomes, by irradiating at $760 \mathrm{~nm}(10 \mathrm{~mW})$ for 2 $\min$.

Encapsulated photosensitizers have also been used for phototriggered drug release from liposomes [79, 80]. Irradiation at specific wavelengths (which depend on the photosensitizer) produces singlet oxygen, which can oxidize lipids containing unsaturated fatty acids in the liposomes, resulting in increased lipid bilayer permeability and release of cargo. Photoresponsive liposomes have also been made by covalently linking photosensitizers to phospholipids [89], which enhanced retention of the photosensitizer, and hence more stable photoresponsiveness.

\section{Polymeric micelles}

Polymeric micelles are typically composed of amphiphilic block copolymers which selfassemble by hydrophobic interactions in aqueous solution so that the hydrophobic blocks form the core and hydrophilic chains form the shell. The hydrophobic core provides a reservoir to store hydrophobic therapeutic molecules [90]. The disruption of polymeric micelles by irradiation has been studied in the last decade [43, 50]. Typically, photoresponsive amphiphilic copolymers bear photocleavable groups in the hydrophobic block, cleavage of which renders the hydrophobic block hydrophilic. As a result, the micelles dissociate, releasing encapsulated molecules. This dissociation process can be rendered reversible by the use of photoswitchable groups, such as azobenzene, spiropyran, and dithienylethene $[43,48]$.

In early examples of light-dissociable polymeric micelles, block copolymers consisted of one hydrophilic poly(ethylene glycol) (PEG) block and one hydrophobic poly(methacrylate) (PMA) block with side chains bearing photocleavable groups, such as pyrenylmethyl [91], $o$-nitrobenzyl [92] and [7-(diethylamino)coumarin-4-yl]methyl (DEACM) [93] chromophores. The block copolymers self-assembled in aqueous solution to form a coreshell structure, where PEG formed the shell and PMA the core. The PMA core could encapsulate hydrophobic molecules. Upon UV irradiation, the chromophores were removed from the hydrophobic PMA chains, generating hydrophilic poly(methacrylic acid) (PMAA). 
The resulting disruption of micellar hydrophobic-hydrophilic balance led to the disassociation of the micelles and the release of the encapsulated compounds. This strategy was used for phototriggered release of doxorubicin [94]. In another example of micellar hydrophobic-hydrophilic disruption, photocleavable groups were incorporated within the main chains of hydrophobic blocks so that irradiation degraded the polymer blocks forming the micellar core, releasing drug molecules loaded therein [95, 96]. A hydrophobichydrophilic disruption mechanism was also used to release guest molecules from dendritic amphiphile-based micelles [97].

Drug release can also be rendered light-triggerable by conjugating the drug to the micelle with a photocleavable group. For example, the chemotherapeutic drug camptothecin was covalently linked to the hydrophobic chain in a micelle by a photolabile $o$-nitrobenzyl derivative. Upon irradiation with an UV lamp ( $365 \mathrm{~nm}, 15 \mathrm{~min}$ ), drug was released and the toxicity of the irradiated drug-linked particles against human lung adenocarcinoma A549 cells was enhanced 9.7-fold [98].

Hydrophilic agents can be incorporated into photoresponsive polymeric micelles. For example, an amphiphilic copolymer with an $o$-nitrobenzyl moiety on the junction between a long hydrophobic tail and a cationic head was synthesized which could self-assemble into nanoparticles with a hydrophobic core and cationic shell [99]. siRNA was loaded onto the cationic shell by electrostatic interaction. Irradiation with UV light cleaved the $o$-nitrobenzyl linker and separated the hydrophilic shell from the core, releasing the siRNA. UVirradiation (maximum wavelength at $365 \mathrm{~nm}, 10 \mathrm{~mW} / \mathrm{cm}^{2}, 5 \mathrm{~min}$ ) of the nanoparticles enhanced the gene silencing effect of the complexes in human breast cancer cells (MDAMB-231) by $50 \%$.

Efforts to trigger particles with longer wavelengths of light have led to the use of coumarin-4-ylmethyl derivatives, which absorb visible light [47]. A chitosan-based nanoparticle was designed for phototriggered release of anticancer drugs under the hypoxic conditions prevailing in tumors (Figure 6) [100]. An electron acceptor, nitroimidazole, was covalently linked to a coumarin-based moiety, which connected the drugs to the chitosan molecules. In normal tissues, photocleavage of the coumarin group (leading to drug release) was prevented by photoinduced electron transfer (PET), whereby photoexcited electrons were transferred from the coumarin group to the nitroimidazole electron acceptor. Only in anaerobic conditions would the reduction of nitroimidazole allow photocleavage of the coumarin group, releasing the coumarin-linked anticancer drug etoposide. The nanoparticles' cytotoxicity was greatly increased in hypoxic conditions when exposed to visible light $\left(\lambda>400 \mathrm{~nm}, 120 \mathrm{~mW} / \mathrm{cm}^{2}, 20 \mathrm{~min}\right)$.

Spiropyran photoisomerization was used as the basis of a photoshrinkable nanoparticle (Figure 7) [101, 102]. Nanoparticles were formed by self-assembly of alkyl derivatives of the chromophore spiropyran, hydrophobic drugs, and lipid-PEG chains. Upon UV light irradiation $\left(365 \mathrm{~nm}, 1 \mathrm{~W} / \mathrm{cm}^{2}, 10 \mathrm{~s}\right)$, hydrophobic spiropyran underwent isomerization to zwitterionic merocyanine, which induced nanoparticle shrinkage from $150 \mathrm{~nm}$ to $40 \mathrm{~nm}$ and triggered drug release. Irradiated particles were able to penetrate deeper into the cornea $e x$ vivo, and into mouse tumors in vivo, enhancing chemotherapeutic efficacy. This alkyl- 
spiropyran based nanoparticle did not dissociate upon irradiation, due to the hydrophobicity of the alkyl chains. Photoisomerization did result in micelle dissociation when the spiropyran was linked to a hydrophilic block copolymer, due to the recovery of the polymer's hydrophilicity [103].

Two-photon absorption of NIR light has been utilized to achieve the same chemical reaction as by one-photon UV/visible light, but with deeper tissue penetration, e.g., to disrupt polymeric micelles bearing photosensitive groups such as DNQ [49], o-nitrobenzyl [91, 104] and DEACM [93] groups. This approach has been used to release doxorubicin [105-107], rifampicin and paclitaxel [108] from micelles. For example, doxorubicin-loaded polymeric micelles were made with DNQ-conjugated linear-dendritic amphiphiles [107]. The hydrophobic DNQ could be transformed to hydrophilic 3-indenecarboxylic acid by NIR irradiation ( $808 \mathrm{~nm}, 500 \mathrm{~Hz}$, pulse duration: $<2 \mathrm{~ms}, 500 \mathrm{~mW}$; $30 \mathrm{~min}$ ) via a two-photon absorption process. The resulting hydrophobicity change of the DNQ groups disrupted the micelles and released the encapsulated doxorubicin. Cytotoxicity against human cervical cancer HeLa cells was significantly enhanced by two-photon irradiation.

\section{Polymersomes}

Polymersomes are polymeric vesicles composed of amphiphilic block copolymers that selfassemble forming a bilayer shell around an aqueous core [109]. The inner core of polymersomes can encapsulate hydrophilic molecules and the bilayer membrane can integrate hydrophobic compounds. Polymersomes can be made to release drugs in response to stimuli [110], and can be made photoresponsive by using amphiphilic copolymers with suitable photosensitive groups, such as azobenzene [111] and $o$-nitrobenzyl groups [112, 113]. For example, polymersomes have been made from photocleavable amphiphilic block copolymers, such as poly(methyl caprolactone)-o-nitrobenzyl-poly(acrylic acid) (PMCLONB-PAA) [114] (the nitrobenzyl moiety makes it photocleavable). UV light irradiation cleaved the diblock copolymer, separating the shell PAA chains from the hydrophobic PMCL layer. The resulting destabilization of the PMCL core caused the release of $61 \%$ of encapsulated protein after $5 \mathrm{~min}$ of UV irradiation $\left(365 \mathrm{~nm}, 200 \mathrm{~mW} / \mathrm{cm}^{2}\right)$. Recently, two anticancer drugs, hydrophilic doxorubicin (DOX $\cdot \mathrm{HCl})$ and hydrophobic camptothecin, have been encapsulated in photoresponsive polymersomes and could be released upon UV light irradiation due to an increase in membrane permeability or degradation of the bilayer membrane $[115,116]$.

Polymersomes can also be triggered by irradiating encapsulated photosensitizers. For example, polyion complex vesicles were formed by oppositely charged poly(ethylene glycol)-poly(aspartic acid) and poly([5-amino-penyl]- $\alpha \beta$-aspartamide) polymer chains [117]. An amphiphilic photosensitizer, AIPcS2a, was loaded in the inner aqueous phase. The release of AIPcS2a was prevented by cross-linking the polymer chains forming the vesicle membranes. Upon NIR light irradiation $(680 \mathrm{~nm})$, reactive oxygen species (ROS) were generated by AIPcS2a and disrupted the integrity of the particle membranes, inducing the release of AIPcS2a. In cancer cell culture, the ROS damaged endo/lysosomal membranes, further releasing AlPcS2a to the cytoplasm and enhancing photocytoxicity. The strategy of 
using a photosensitizer to enhance drug escape from endo/lysosomes is known as photochemical internalization (PCI) [118-121].

\section{Nanogels}

Nanogels are cross-linked networks made of hydrophilic or amphiphilic polymers. Their hydrophilic properties enable them to deliver a wide range of hydrophilic drugs and proteins [122]. Nanogels have been made photoresponsive. For example, dextran nanogels were formed by using the physical crosslinks between the polymers' phydrophobic azobenzene side chains [123]. Irradiation with UV light ( $\left.365 \mathrm{~nm}, 10 \mathrm{~mW} / \mathrm{cm}^{2}, 2.5 \mathrm{~min}\right)$ induced trans to cis isomerization of the azobenzenes, which changed their polarity. These changes weakened the hydrophobic interaction between azobenzenes, releasing the encapsulated drugs. In addition, nanogels with photocleavable crosslinks released encapsulated proteins upon irradiation with UV light at $365 \mathrm{~nm}$ [124].

Encapsulating plasmonic nanoparticles into drug-loaded thermo-responsive nanogels can perform both photothermal therapy and triggered drug release [125]. A core-shell nanogel was designed so that the thermo-responsive PEG-based shell would shrink when heated by the Au-Ag plasmonic core. When irradiated by NIR light $\left(1.5 \mathrm{~W} / \mathrm{cm}^{2}, 5 \mathrm{~min}\right)$, those nanogels loaded with the anticancer drug temozolomide were able to kill mouse melanoma cells, presumably by a combination of photothermal (direct heating of cells) and chemotherapeutic effects.

\section{Solid organic nanoparticles}

Solid organic particles are primarily composed of hydrophobic compounds and have been rendered photoresponsive by a variety of mechanisms [126, 127], including photothermal effects [128], photocrosslinking [129, 130], and photocleavage [131, 132]. These processes induce a change of particle size, polarity, or porosity to drive the release of encapsulated drugs.

Polymeric nanoparticles can increase in size and release drugs when irradiated. Nanoparticles made of cross-linked polymethacrylates with positively charged amine side chains were caged (rendered non-cationic) by photolabile hydrophobic groups [133]. Upon irradiation with UV light $\left(365 \mathrm{~nm}, 11 \mathrm{~mW} / \mathrm{cm}^{2}, 15 \mathrm{~min}\right)$, the side chains were uncaged to expose the cationic amines, inducing a $>300$-fold increase in nanoparticle volume, causing concomitant drug (curcumin) release, resulting in increased cytotoxicity in HeLa cells.

Introduction of photolabile groups into the polymer backbone can lead to its cleavage into small fragments, resulting in the release of encapsulated compounds [132, 134]. For example, nanoparticles were made of a polyurethane with photolabile 2-nitrophenylethylene glycol moieties in the polymer backbone (Figure 8) [134]. Upon irradiation with UV light $\left(365 \mathrm{~nm}, 11 \mathrm{~mW} / \mathrm{cm}^{2}, 2 \mathrm{~min}\right)$ an encapsulated dye was released. Particles loaded with a model drug (Tagalsin G, a steroid from marine sources) caused 67\% cell death in culture when irradiated $\left(365 \mathrm{~nm}, 11 \mathrm{~mW} / \mathrm{cm}^{2}, 10 \mathrm{~min}\right)$, while cell death was only $9 \%$ without irradiation. 


\section{Mesoporous silica nanoparticles}

Mesoporous silica nanoparticles (MSNPs) possess desirable properties for drug delivery, such as large pore volume, tunable pore size and versatile silane chemistry for surface functionalization [135-137]. The encapsulation and release of therapeutic agents can be regulated by the "gatekeeper" strategy [138-140], in which gate-like chemical entities can be constructed on the pore outlets, blocking the pores and preventing drug release. These gates can be opened by external stimuli, including light. An example of such a photoregulated gate is seen in coumarin derivatives covalently linked on the pore outlets of MSNPs [141, 142], so that irradiation with $>310 \mathrm{~nm}$ UV light induced their dimerization, which closed the pores. The gates could be opened by irradiation at $250 \mathrm{~nm}$ that separated the dimers, releasing the molecules within. MSNP pores have also been capped by gold nanoparticles through electrostatic interaction between the negatively charged MSNPs and gold nanoparticles functionalized with a cationic $o$-nitrobenzyl derivative. Irradiation with UV light $\left(365 \mathrm{~nm}, 0.49 \mathrm{~mW} / \mathrm{cm}^{2}, 10 \mathrm{~min}\right.$ ) cleaved the $o$-nitrobenzyl groups so that the gold nanoparticles developed a negative charge. The resulting charge repulsion between the MSNPs and the gold nanoparticles upcapped the pores and released the anticancer drug paclitaxel [143]. In another example, single-stranded DNA attached to the pore outlets of MSNP were hybridized to single-stranded DNA which blocked the pores. That blocking DNA contained azobenzenes in the nucleic acid backbone of the complementary sequences. UV irradiation ( $365 \mathrm{~nm}, 6 \mathrm{~W}, 30 \mathrm{~min}$ ) induced photoisomerization of the azobenzene moieties, which dehybridized the DNA strands, unblocked the pores, and allowed release of doxorubicin from the pores [144]. MSNPs have also been coated with a spiropyrancontaining amphiphilic copolymer, which made their release of doxorubicin phototriggerable (365 $\left.\mathrm{nm}, 200 \mathrm{~mW} \mathrm{~cm}{ }^{-2}, 20 \mathrm{~min}\right)$ [145].

Photoresponsive MSNPs have been used for drug delivery in optically transparent zebrafish larvae (Figure 9) [146]. MSNPs were functionalized with [2] rotaxanes consisting of an acyclodextrin $(\mathrm{CD})$ ring threaded with a linear trans-azobenzene axle so that the a-CD ring was away from the pore outlet of MSNPs and did not block the pores, allowing the loading of drug molecules into the pores. Upon irradiation at $365 \mathrm{~nm}$, the trans-to-cis isomerization of the azobenzene moiety moved the a-CD ring so that it blocked the pore. Heat and visible light irradiation both induced cis-to-trans isomerization of the azobenzene unit, unblocking the pores and allowing the release of encapsulated curcumin. The ability to phototrigger drug release was demonstrated with visible light irradiation (halogen $12 \mathrm{~V}, 100 \mathrm{~W}$ lamp, $40 \%$ of maximal intensity, $1 \mathrm{~h}$ ) in zebrafish larvae.

Azobenzene derivatives that have one end tethered onto the pore surface of MSNPs can also control drug release by the "impeller" effect $[147,148]$ : when irradiated at a wavelength absorbed by both the trans and cis azobenzene isomers, trans-cis isomerizations occur simultaneously in both directions on the pore surface and result in the continual dynamic wagging of the untethered end of the azobenzene units. The azobenzene moiety then acts as an impeller and expels entrapped molecules from the pores. In another example, an azobenzene derivative and a two-photon fluorophore were both attached to the pore surface of MSNPs. Upon two-photon excitation in the NIR range, Förster resonance energy transfer (FRET) from the fluorophores to the azobenzenes triggered the reversible isomerization of 
the azobenzenes, which then acted as impellers [149]. Irradiation with a focused laser beam $\left(760 \mathrm{~nm}, 900 \mathrm{~mW} / \mathrm{cm}^{2}\right.$, three scans of $1.57 \mathrm{~s}$ duration) triggered the release of camptothecin from the pores by the "impeller" effect, inducing cancer cell death.

Photoresponsive drug release from MSNPs has also been achieved by covalently conjugating drug molecules to their surfaces with a photocleavable group. For example, the anticancer drug chlorambucil was grafted onto the surface of MSNPs using a photolabile 7amino-coumarin derivative as the linker [150]. Cleavage of the coumarin linker and release of the drug was triggered by irradiation with visible light $\left(\lambda>400 \mathrm{~nm}, 120 \mathrm{~mW} / \mathrm{cm}^{2}\right)$ for 15 min. Cytotoxicity against HeLa and MCF-7 cells was enhanced by irradiation of the drugloaded MSNPs. This strategy can also be applied to other types of drug vehicles, such as nonporous silica nanoparticles [151].

\section{Upconverting nanoparticles}

Upconverting nanoparticles (UCNPs), usually lanthanide-doped nanocrystals, can achieve the conversion of NIR to lower wavelength light (anti-Stokes wavelength conversion) [152, 153]. To increase the NIR absorption of UCNPs, $\mathrm{Yb}^{3+}$ is often co-doped with other lanthanide ions (e.g. $\mathrm{Er}^{3+}, \mathrm{Tm}^{3+}$ and $\mathrm{Ho}^{3+}$ ) in $\mathrm{NaYF}_{4}$ nanocrystals. The theory underlying the chemistry of UCNPs has been reviewed in detail [154]. These UCNPs can convert NIR light (usually $980 \mathrm{~nm}$ ) to multiwavelength light in the UV-Visible-NIR region of the spectrum; the exact wavelength depends on the composition of dopant(s). The resulting UV/ visible light can conduct photochemical reactions on the surface of the UCNPs or within a polymer or silica shell surrounding them. Recently, there has been increasing interest in the development of UCNP-based nanomaterials for biomedical applications, such as biomedical imaging, photodynamic therapy and drug delivery [54, 153, 155-157].

As an example of photocleavage of a compound from a UCNP, acetic acid was cleaved from 3',5'-di(carboxymethoxy)benzoin acetate attached on $\mathrm{NaYF}_{4}: \mathrm{Tm} \mathrm{Yb} @ \mathrm{NaYF}_{4}$ UCNPs by UV light upconverted from NIR irradiation $\left(980 \mathrm{~nm}, 556 \mathrm{~W} / \mathrm{cm}^{2}\right)$ [158]. Using a similar photochemistry, $\mathrm{NaYF}_{4}: \mathrm{Tm} \mathrm{Yb}$ UCNPs incorporated into the core of photoresponsive micelles enabled $980 \mathrm{~nm}$ laser irradiation $(5 \mathrm{~W}, 4 \mathrm{~h})$ to disrupt the micelles by cleavage of a $o$-nitrobenzyl moiety [159]. The requirement for high irradiances should be noted in many studies of UCNPs. UCNPs have been used to release drugs as follows.

Release of conjugated drugs-Therapeutic molecules directly conjugated to UCNPs by photocleavable linkers can be released by the upconverted light. An $o$-nitrobenzyl derivative of the anticancer drug 5-fluorouracil was covalently conjugated to $\mathrm{NaYF}_{4}: \mathrm{Tm} \mathrm{Yb}$ UCNPs [160]. Continuous irradiation with a $980 \mathrm{~nm}$ NIR laser $(30 \mathrm{~mW})$ for approximately 14 min cleaved the $o$-nitrobenzyl groups and released 5-fluorouracil. This approach could be applied to other therapeutic agents and different photocleavable groups.

Photorelease of active drugs from UCNPs can also be achieved by using a photoactivatable prodrug $[161,162]$. For example, the UV-activatable platinum (IV) prodrug trans,trans,trans-[Pt $\left.\left(\mathrm{N}_{3}\right)_{2}\left(\mathrm{NH}_{3}\right)(\mathrm{py})\left(\mathrm{O}_{2} \mathrm{CCH}_{2} \mathrm{CH}_{2} \mathrm{COOH}\right)_{2}\right]$ was conjugated to $\mathrm{NaYF}_{4}: \mathrm{Tm}$ $\mathrm{Yb} @ \mathrm{NaGdF}_{4}: \mathrm{Yb}$ core-shell UCNPs coated with polyethylenimine (Figure 10) [161]. Upon irradiation at $980 \mathrm{~nm}\left(2.5 \mathrm{~W} / \mathrm{cm}^{2}\right.$, total of $\left.30 \mathrm{~min}\right)$, the UCNPs converted the NIR light to 
UV/visible light, activating the prodrug (trans-platinum (IV)) to the drug platinum (II) and enhancing release of the free drug. The NIR-irradiated UCNPs had better tumor growth inhibition efficacy than did UV-irradiated ones, presumably because NIR light can penetrate tissue more deeply than can UV light.

Release of physically loaded drugs-Therapeutic agents physically loaded into UCNP-based nanocarriers can be released by the conformational changes the carriers undergo upon NIR light irradiation. The anticancer drug doxorubicin was loaded into the pores of a mesoporous silica shell coating on NaYF4:Tm Yb@ NaYF4 UCNPs, where they remained bound by hydrogen bonding and electrostatic interaction with the MSNPs' surface silanol groups [163]. Azobenzene groups were tethered by one end to the surface of the silica pores. Upon irradiation with $980 \mathrm{~nm}$ NIR light, the UCNPs emitted both UV (350 nm) and visible light $(450 \mathrm{~nm})$ that caused reversible tran-cis photoisomerization of the azobenzene molecules. This continuous movement propelled the release of loaded doxorubicin in a controllable fashion by the "impeller" effect as discussed above. Such UCNPs loaded with doxorubicin showed enhanced toxicity against HeLa cells upon irradiation at $980 \mathrm{~nm}\left(2.4 \mathrm{~W} / \mathrm{cm}^{2}, 20 \mathrm{~min}\right)$. In a related approach, the isomerization between positively charged merocyanine and neutral spiropyran triggered by $980 \mathrm{~nm}$ light irradiation $\left(0.5 \mathrm{~W} / \mathrm{cm}^{2}, 20 \mathrm{~min}\right.$ total irradiation) has been used to release the entrapped negatively charged enzyme, $\beta$-galactosidase, from hollow $\mathrm{NaYF}_{4}: \mathrm{Yb}$ Er UCNPs into living cells [164].

Irradiation of photocleavable moieties has been used to release siRNA [165], doxorubicin [166] and dye molecules $[167,168]$ from UCNP-based nanosystems. For example, $\mathrm{NaYF}_{4}: \mathrm{Tm} \mathrm{Yb} \mathrm{UCNPs} \mathrm{were} \mathrm{coated} \mathrm{with} \mathrm{a} \mathrm{silica} \mathrm{layer,} \mathrm{which} \mathrm{was} \mathrm{further} \mathrm{functionalized}$ with a cationic alkyl amine via a photocleavable $o$-nitrobenzyl linker [165]. Negatively charged siRNA molecules were bound to the surface of the UCNPs by electrostatic interaction with the cationic alkyl amine. Upon $980 \mathrm{~nm}$ laser irradiation $\left(5.6 \mathrm{~W} / \mathrm{cm}^{2}, 2 \mathrm{~h}\right)$, the upconverted UV light from UCNPs cleaved the $o$-nitrobenzyl-linked alkyl amine from the surface of the UCNPs, resulting in the release of siRNA inside HeLa cells, successfully silencing EGFP gene expression.

UCNPs have also been used to photoactivate prodrugs encapsulated within nanocarriers. Nanoparticles with a $\mathrm{NaYF}_{4}: \mathrm{Tb} \mathrm{Tm} @ \mathrm{NaLuF}_{4} \mathrm{UCNP}$ core and a mesoporous silica shell were loaded with a prodrug of the cancer chemotherapeutic chlorambucil (Figure 11) [169]. The prodrug was more hydrophobic than the parent drug because of a photolabile aminocoumarin derivative and was therefore retained inside the shell. When the nanoparticles were irradiated with $980 \mathrm{~nm}$ NIR light, the UCNPs emitted UV light, which cleaved the coumarin group, triggering the release of the more hydrophilic chlorambucil. In vivo, irradiated $\left(50 \mathrm{~mW} / \mathrm{cm}^{2}, 20 \mathrm{~min}\right.$ per day for 16 days) nanoparticles significantly decreased the tumor size in mice.

Lanthanide-based UCNPs are interesting components of nanocarriers for phototriggered drug release, but several issues remain to be addressed. Their biocompatibility has been studied $[170,171]$ but there is no definitive conclusion on whether it is acceptable. The quantum yield of upconverting processes is relatively low (usually $<1 \%$ ), which often necessitates high irradiances. Another challenge stems from the fact that most UCNPS are 
excited at $980 \mathrm{~nm}$, where absorption by water attenuates transmission of power to the target and causes heating. Efforts have been made to improve the quantum yield of UCNPs and to make them excitable at different wavelengths (e.g. around $800 \mathrm{~nm}$ ) [157, 172-174].

\section{Phototriggered targeting (phototargeting) of nanoparticles}

Light can be used to determine the timing and specific location at which nanoparticles will bind to tissues, to improve efficacy and decrease toxicity. Proof-of-concept of phototargeting was provided by a nanoparticle whose surface was decorated with a peptide ligand (YIGSR), and which was inactivated by caging with a photocleavable group, 4,5dimethoxy-2-nitrobenzyl (DMNB) [175]. In the absence of light, the nanoparticles would not bind to cells, but when irradiated at $365 \mathrm{~nm}$, the DMNB group was cleaved from the YIGSR, allowing the nanoparticles to bind to cells bearing integrin $\beta 1$, the target for YIGSR. Since integrin $\beta 1$ is widely distributed on many cell types throughout the body, this approach could in theory allow nanoparticles to bind specifically to any tissues that can be irradiated. This approach also has the advantage over conventional ligand-targeted nanotherapies of not requiring a tissue-specific ligand, or even of not requiring knowledge of a tissue-specific disease marker.

Phototriggered targeting of nanoparticles has been applied with other ligands, such as cellpenetrating peptides [176] and folic acid [177, 178]. Phototriggered targeting has also been demonstrated in vivo (Figure 12) [178] with UCNPs that convert NIR to UV light. The ligand, folic acid, was caged with a photocleavable $o$-nitrobenzyl group and conjugated to UCNPs via a PEG linker. Upon irradiation with a $980 \mathrm{~nm}$ laser, the UCNPs emitted UV light (360 nm), cleaving the caging group and revealing the folic acid which could then bind to cells expressing folate receptors. Doxorubicin could also be bound to the surface of the UCNPs with a disulfide bond that could be cleaved by lysosomal enzymes in cells. The UCNPs were administered intravenously to tumor-bearing mice. Irradiated tumors (980 nm, $1.8 \mathrm{~W} / \mathrm{cm}^{2}, 1 \mathrm{~h}$ ) showed more UCNP accumulation and enhanced tumor inhibition compared to those without irradiation.

In the examples above, the caging groups were required to bind directly to the functional sites of the ligands in order to deactivate them. Another strategy is to position ligands in such a manner that the particle surface architecture prevents them from interacting with their targets on the cell surface. For example, the surfaces of liposomes were modified with a construct wherein a cell penetrating peptide was flanked by a PEG chain on one side and a photocleavable $o$-nitrobenzyl group on the other, and by alkyl chains on both sides beyond them [179]. In the liposome membrane, the construct took on a looped structure with the alkyl chains embedded in the lipid bilayer and the PEG preventing the peptide from interacting with target cells. Irradiation with a UV lamp cleaved the $o$-nitrobenzyl moiety, exposing the peptide still tethered to the particle surface by PEG. Biotin ligands on polymeric nanoparticles have been controlled by UV light by a similar strategy [180].

NIR irradiation of gold nanoshells can also be used to recover the function of surface-bound ligands blocked by steric hindrance [181]. YIGSR peptides were bound to the surface of silica core-gold shell nanoparticles but were prevented from binding to cells by a coating of 
thermoresponsive pNIPAAm-co-pAAm copolymer that had a longer chain than the peptide. Upon NIR irradiation ( $808 \mathrm{~nm}, 1.2 \mathrm{~W} / \mathrm{cm}^{2}, 4 \mathrm{~min}$ ), the gold nanoshells heated up, which caused the collapse of the copolymer and exposure of the peptide, allowing cell binding.

\section{Opportunities and challenges}

The idea that light-directed therapies could be used in humans has been validated by the nascent clinical use of plasmonic nanoparticles for photothermal therapy [182], and of liposomes for localized photodynamic therapy [77]. Translation of photoresponsive nanoparticles would enable precise targeted delivery $[175,178,181]$ and on-demand release of therapeutics $[16,42]$. The ability to spatially and temporally control drug release kinetics could potentially decrease in vivo drug toxicity and increase therapeutic efficacy, i.e., improve the therapeutic index.

Light can also be used in combination with other stimuli such as $\mathrm{pH}$ [95] [183], temperature [184, 185], and redox potential [186, 187]. The various stimulus combinations can be designed in systems where all stimuli are needed to trigger cargo release $[183,186]$ or where one of the stimuli can activate the release [187]. In addition to combining different stimuli, phototriggered drug release can be designed in a wavelength-selective manner [188], where irradiation of certain wavelengths can trigger the release of specific drugs in a multi-drug depot.

Further development of the properties of photoresponsive molecules will enhance the applicability of these drug delivery systems. For example, having higher quantum yields and better absorption at wavelengths in the NIR window could reduce the irradiance and time required to achieve a given effect. This would benefit the practicality and effectiveness of the systems and reduce their potential light toxicity. The latter - the potential for burns - is a serious limitation to translation. (Note that the temperature at the nanoparticle surface is not necessarily the problem here, it is the bulk heating of tissue.) In that regard, it would be helpful if more studies addressed what the expected effects on living creatures would be of the energies required to trigger the particles described. (In fact, important technical details regarding the light used for photoactivation (e.g., wavelength and irradiance) are frequently reported in an incomplete manner, making difficult the assessment of their phototoxicity and of their practicality compared to other formulations.)

In a related vein, it would undoubtedly be helpful to have more reports of the use of these systems in vivo, where they may not work as well as they did in vitro, especially when not assisted by EPR and similar phenomena.

For clinical applications, the light source that serves as the external stimulus should be easy to use, reliable, affordable, and - ideally - readily portable. It is hoped that advances in laser technology will meet those criteria. Advances in optical fiber technology will enhance the ability to provide light endoscopically deep within the body [189].

Despite the promising potential of light-responsive drug delivery in nanomedicine, much remains to be done. The biocompatibility of many of the photoresponsive moieties or materials incorporated in nanocarriers has not been studied systematically. It is important to

Nano Today. Author manuscript; available in PMC 2016 August 01. 
thoroughly evaluate the safety of the all components of the drug delivery system, including the drugs to be delivered, locally and systemically $[16,190]$.

Nanoparticles that respond to UV or visible light may be limited in application due to poor tissue penetration (advances in endoscopy notwithstanding). UCNPs and other approaches that convert NIR light to light of shorter wavelengths may make it possible to use such systems. However, the development of UCNPs for biomedical application is still at an early stage. Further improvements are needed on properties such as quantum yield, tunable excitation wavelengths, and tunable sizes. Their biocompatibility needs to be better understood.

It will also be important to improve the materials of which photoresponsive materials are made. For example, thermosensitive polymers that undergo a greater phase change in response to a given increment in temperature, and/or more efficient means of coupling thermosensitive materials to the plasmonic nanoparticles that heat them will reduce the irradiance needed to trigger drug delivery or targeting. Such improvements may affect nanoparticle performance and enhance safety by reducing the probability of thermal injury.

There are many technical difficulties to be addressed, such as minimizing release from the nanoparticles when they are not triggered (i.e., in the off-state), achieving repeated drug release with repeated irradiation, and minimizing non-specific binding to tissues. One practical problem is a byproduct of one of the strengths of photoresponsive systems: that the treatments are preferentially triggered at specific locations selected by a human operator of a light source. This can be disadvantageous if the location of the target tissue is not known (e.g., metastases). It is therefore likely that these technologies will become paired with imaging modalities to help with target acquisition.

Although the field of photoresponsive nanoparticles is still in its infancy, there has been a lot of progress in many topics that will facilitate future improvements. It is likely that progress will accelerate as advances are made in related fields, as discussed above.

\section{Acknowledgments}

This work was supported by National Institutes of Health (NIH) Grant GM073626 (to D.S.K.).

\section{References}

1. Uhrich KE, Cannizzaro SM, Langer RS, Shakesheff KM. Chem Rev. 1999; 99:3181-3198. [PubMed: 11749514]

2. Peer D, Karp JM, Hong S, Farokhzad OC, Margalit R, Langer R. Nat Nanotechnol. 2007; 2:751760. [PubMed: 18654426]

3. Cho K, Wang X, Nie S, Chen Z, Shin DM. Clin Cancer Res. 2008; 14:1310-1316. [PubMed: 18316549]

4. Zhu X, Radovic-Moreno AF, Wu J, Langer R, Shi J. Nano Today. 2014; 9:478-498. [PubMed: 25267927]

5. Bunjes H. J Pharm Pharmacol. 2010; 62:1637-1645. [PubMed: 21039547]

6. Wang Y, Li Z, Han Y, Liang LH, Ji A. Curr Drug Metab. 2010; 11:182-196. [PubMed: 20359287]

7. Albanese A, Tang PS, Chan WCW. Annu Rev Biomed Eng. 2012; 14:1-16. [PubMed: 22524388]

8. Farokhzad OC, Langer R. ACS Nano. 2009; 3:16-20. [PubMed: 19206243] 
9. Kost J, Langer R. Adv Drug Deliv Rev. 2001; 46:125-148. [PubMed: 11259837]

10. Kim CS, Duncan B, Creran B, Rotello VM. Nano Today. 2013; 8:439-447. [PubMed: 24159362]

11. Epstein-Barash H, Orbey G, Polat BE, Ewoldt RH, Feshitan J, Langer R, Borden MA, Kohane DS. Biomaterials. 2010; 31:5208-5217. [PubMed: 20347484]

12. Hoare T, Timko BP, Santamaria J, Goya GF, Irusta S, Lau S, Stefanescu CF, Lin D, Langer R, Kohane DS. Nano Lett. 2011; 11:1395-1400. [PubMed: 21344911]

13. Timko BP, Arruebo M, Shankarappa SA, McAlvin JB, Okonkwo OS, Mizrahi B, Stefanescu CF, Gomez L, Zhu J, Zhu A, Santamaria J, Langer R, Kohane DS. Proc Natl Acad Sci U S A. 2014; 111:1349-1354. [PubMed: 24474759]

14. Huang Z. Technol Cancer Res Treat. 2005; 4:283. [PubMed: 15896084]

15. Glickman RD. Int J Toxicol. 2002; 21:473-490. [PubMed: 12537644]

16. Timko BP, Dvir T, Kohane DS. Adv Mater. 2010; 22:4925-4943. [PubMed: 20818618]

17. Timko BP, Whitehead K, Gao W, Kohane DS, Farokhzad O, Anderson D, Langer R. Ann Rev Mater Res. 2011; 41:1-20.

18. Timko BP, Kohane DS. Isr J Chem. 2013; 53:728-736.

19. Timko BP, Kohane DS. Clin Ther. 2012; 34:S25-S35. [PubMed: 23149010]

20. Timko BP, Kohane DS. Expert Opin Drug Deliv. 2014; 11:1681-1685. [PubMed: 25008774]

21. Welch, AJ.; van Gemert, MJC. Optical-Thermal Response of Laser Irradiated Tissue, second ed. Springer; New York: 2011.

22. Steiner, R. Laser-Tissue Interactions. In: Raulin, C.; Karsai, S., editors. Laser and IPL Technology in Dermatology and Aesthetic Medicine. Springer; Berlin: 2011. p. 23-36.

23. Cheong WF, Prahl SA, Welch AJ. IEEE J Quantum Electron. 1990; 26:2166-2185.

24. Tuchin VV. Phys Usp. 1997; 40:495-515.

25. Ntziachristos V, Ripoll J, Weissleder R. Opt Lett. 2002; 27:333-335. [PubMed: 18007794]

26. Simpson CR, Kohl M, Essenpreis M, Cope M. Phys Med Biol. 1998; 43:2465-2478. [PubMed: 9755939]

27. Steven LJ. Phys Med Biol. 2013; 58:R37-R61. [PubMed: 23666068]

28. Bowen WJ. J Biol Chem. 1949; 179:235-245. [PubMed: 18119239]

29. Weissleder R. Nat Biotechnol. 2001; 19:316-317. [PubMed: 11283581]

30. Peters VG, Wyman DR, Patterson MS, Frank GL. Phys Med Biol. 1990; 35:1317. [PubMed: 2236211]

31. Davies MJ, Truscott RJW. J Photochem Photobiol B-Biol. 2001; 63:114-125.

32. Podda M, Traber MG, Weber C, Yan LJ, Packer L. Free Radic Biol Med. 1998; 24:55-65. [PubMed: 9436614]

33. Kumar V, Lockerbie O, Keil SD, Ruane PH, Platz MS, Martin CB, Ravanat JL, Cadet J, Goodrich RP. Photochem Photobiol. 2004; 80:15-21. [PubMed: 15339215]

34. Boulnois JL. Laser Med Sci. 1986; 1:47-66.

35. Peeters S, Kitz M, Preisser S, Wetterwald A, Rothen-Rutishauser B, Thalmann GN, Brandenberger C, Bailey A, Frenz M. Biomed Opt Express. 2012; 3:435-446. [PubMed: 22435092]

36. Lapotko D, Lukianova E, Potapnev M, Aleinikova O, Oraevsky A. Cancer Lett. 2006; 239:36-45. [PubMed: 16202512]

37. Matylevitch NP, Schuschereba ST, Mata JR, Gilligan GR, Lawlor DF, Goodwin CW, Bowman PD. Am J Pathol. 1998; 153:567-577. [PubMed: 9708816]

38. American National Standard for Safe Use of Lasers. Laser Institute of America; Orlando, FL: 2007.

39. American National Standard for Safe Use of Optical Fiber Communication Systems Utilizing Laser Diode and LED Sources. Laser Institute of America; Orlando, FL: 2012.

40. Barat, K. Laser safety: tools and training. 2. CRC Press; 2014.

41. Alatorre-Meda, M.; Alvarez-Lorenzo, C.; Concheiro, A.; Taboada, P. UV and Near-IR Triggered Release from Polymeric Micelles and Nanoparticles. In: AlvarezLorenzo, C.; Concheiro, A., 
editors. Smart Materials for Drug Delivery. Royal Society of Chemistry; London: 2013. p. 304-348.

42. Fomina N, Sankaranarayanan J, Almutairi A. Adv Drug Deliv Rev. 2012; 64:1005-1020. [PubMed: 22386560]

43. Gohy JF, Zhao Y. Chem Soc Rev. 2013; 42:7117-7129. [PubMed: 23364156]

44. Klan P, Solomek T, Bochet CG, Blanc A, Givens R, Rubina M, Popik V, Kostikov A, Wirz J. Chem Rev. 2013; 113:119-191. [PubMed: 23256727]

45. Alvarez-Lorenzo C, Bromberg L, Concheiro A. Photochem Photobiol. 2009; 85:848-860. [PubMed: 19222790]

46. Pelliccioli AP, Wirz J. Photochem Photobiol Sci. 2002; 1:441-458. [PubMed: 12659154]

47. Furuta, F. Coumarin-4-ylmethyl Phototriggers. In: Goeldner, M.; Givens, R., editors. Dynamic Studies in Biology: Phototriggers, Photoswitches and Caged Biomolecules. WILEY-VCH; Weinheim: 2005. p. 29-55.

48. Liu G, Liu W, Dong CM. Polym Chem. 2013; 4:3431-3443.

49. Goodwin AP, Mynar JL, Ma Y, Fleming GR, Fréchet JMJ. J Am Chem Soc. 2005; 127:99529953. [PubMed: 16011330]

50. Huang Y, Dong R, Zhu X, Yan D. Soft Matter. 2014; 10:6121-6138. [PubMed: 25046479]

51. Shum P, Kim JM, Thompson DH. Adv Drug Deliv Rev. 2001; 53:273-284. [PubMed: 11744172]

52. Bort G, Gallavardin T, Ogden D, Dalko PI. Angew Chem-Int Edit. 2013; 52:4526-4537.

53. Wu S, Han G, Milliron DJ, Aloni S, Altoe V, Talapin DV, Cohen BE, Schuck PJ. Proc Natl Acad Sci U S A. 2009; 106:10917-10921. [PubMed: 19541601]

54. Zhang Y, Wei W, Das GK, Tan TTY. J Photochem Photobiol C-Photochem Rev. 2014; 20:71-96.

55. Chen G, Qiu H, Prasad PN, Chen X. Chem Rev. 2014; 114:5161-5214. [PubMed: 24605868]

56. Zhou J, Liu Q, Feng W, Sun Y, Li F. Chem Rev. 2014; 115:395-465. [PubMed: 25492128]

57. Link S, El-Sayed MA. J Phys Chem B. 1999; 103:8410-8426.

58. Jain PK, Lee KS, El-Sayed IH, El-Sayed Ma. J Phys Chem B. 2006; 110:7238-7248. [PubMed: 16599493]

59. Wu G, Mikhailovsky A, Khant Ha, Fu C, Chiu W, Zasadzinski Ja. J Am Chem Soc. 2008; 130:8175-8177. [PubMed: 18543914]

60. Huang X, Pallaoro A, Braun GB, Morales DP, Ogunyankin MO, Zasadzinski J, Reich NO. Nano Lett. 2014; 14:2046-2051. [PubMed: 24597503]

61. Jain PK, Qian W, El-Sayed MA. J Am Chem Soc. 2006; 128:2426-2433. [PubMed: 16478198]

62. Sheridan C. Nat Biotechnol. 2012; 30:471-473. [PubMed: 22678364]

63. Soares S, Costa A, Sarmento B. Expert Opin Drug Deliv. 2012; 9:1539-1558. [PubMed: 23098366]

64. Libutti SK, Paciotti GF, Byrnes AA, Alexander HR, Gannon WE, Walker M, Seidel GD, Yuldasheva N, Tamarkin L. Clin Cancer Res. 2010; 16:6139-6149. [PubMed: 20876255]

65. Yavuz MS, Cheng Y, Chen J, Cobley CM, Zhang Q, Rycenga M, Xie J, Kim C, Song KH, Schwartz AG, Wang LV, Xia Y. Nat Mater. 2009; 8:935-939. [PubMed: 19881498]

66. Shi P, Ju E, Ren J, Qu X. Adv Funct Mater. 2014; 24:826-834.

67. Schmaljohann D. Adv Drug Deliv Rev. 2006; 58:1655-1670. [PubMed: 17125884]

68. Barhoumi A, Huschka R, Bardhan R, Knight MW, Halas NJ. Chem Phys Lett. 2009; 482:171-179.

69. Huschka R, Barhoumi A, Liu Q, Roth JA, Ji L, Halas NJ. ACS Nano. 2012; 6:7681-7691. [PubMed: 22862291]

70. Huschka R, Neumann O, Barhoumi A, Halas NJ. Nano Lett. 2010; 10:4117-4122. [PubMed: 20857946]

71. Zharov VP, Letfullin RR, Galitovskaya EN. J Phys D-Appl Phys. 2005; 38:2571-2581.

72. Lapotko DO, Lukianova E, Oraevsky AA. Lasers Surg Med. 2006; 38:631-642. [PubMed: 16736503]

73. Braun GB, Pallaoro A, Wu G, Missirlis D, Zasadzinski JA, Tirrell M, Reich NO. ACS Nano. 2009; 3:2007-2015. [PubMed: 19527019] 
74. Bangham AD, Standish MM, Watkins JC. J Mol Biol. 1965; 13:238-252. [PubMed: 5859039]

75. Chang HI, Yeh MK. Int J Nanomed. 2012; 7:49- 60.

76. Marcato PD, Durán N. J Nanosci Nanotechnol. 2008; 8:2216-2229. [PubMed: 18572633]

77. Bressler NM, Arnold J, Benchaboune M, Blumenkranz MS, Fish GE, Gragoudas ES, Lewis H, Schmidt-Erfurth U, Slakter JS, Bressler SB, Manos K, Hao Y, Haynes L, Koester J, Reaves A, Strong HA, Grp TAPS. Arch Ophthalmol. 2002; 120:1443-1454. [PubMed: 12427056]

78. Yavlovich A, Singh A, Blumenthal R, Puri A. Biochim Biophys Acta-Biomembr. 2011; 1808:117126.

79. Randles EG, Bergethon PR. Langmuir. 2013; 29:1490-1497. [PubMed: 23286452]

80. Thompson DH, Gerasimov OV, Wheeler JJ, Rui Y, Anderson VC. Biochim Biophys ActaBiomembr. 1996; 1279:25-34.

81. Bisby RH, Mead C, Morgan CG. Photochem Photobiol. 2000; 72:57-61. [PubMed: 10911729]

82. Morgan CG, Thomas EW, Sandhu SS, Yianni YP, Mitchell AC. Biochim Biophys Acta. 1987; 903:504-509. [PubMed: 3663656]

83. Liu YC, Le Ny ALM, Schmidt J, Talmon Y, Chmelka BF, Lee CT. Langmuir. 2009; 25:57135724. [PubMed: 19435291]

84. Spratt T, Bondurant B, O’Brien DF. Biochim Biophys Acta-Biomembr. 2003; 1611:35-43.

85. Regen SL, Singh A, Oehme G, Singh M. J Am Chem Soc. 1982; 104:791-795.

86. Gui R, Wan A, Liu X, Jin H. Chem Commun. 2014; 50:1546.

87. Agarwal A, MacKey Ma, El-Sayed Ma, Bellamkonda RV. ACS Nano. 2011; 5:4919-4926. [PubMed: 21591812]

88. Leung SJ, Romanowski M. ACS Nano. 2012; 6:9383-9391. [PubMed: 23106797]

89. Carter KA, Shao S, Hoopes MI, Luo D, Ahsan B, Grigoryants VM, Song W, Huang H, Zhang G, Pandey RK, Geng J, Pfeifer Ba, Scholes CP, Ortega J, Karttunen M, Lovell JF. Nat Commun. 2014; 5:3546. [PubMed: 24699423]

90. Kataoka K, Harada A, Nagasaki Y. Adv Drug Deliv Rev. 2001; 47:113-131. [PubMed: 11251249]

91. Jiang J, Tong X, Zhao Y. J Am Chem Soc. 2005; 127:8290-8291. [PubMed: 15941255]

92. Jiang J, Tong X, Morris D, Zhao Y. Macromolecules. 2006; 39:4633-4640.

93. Babin J, Pelletier M, Lepage M, Allard JF, Morris D, Zhao Y. Angew Chem-Int Edit. 2009; 48:3329-3332.

94. Li Y, Qian Y, Liu T, Zhang G, Liu S. Biomacromolecules. 2012; 13:3877-3886. [PubMed: 23013152]

95. Jin Q, Cai T, Han H, Wang H, Wang Y, Ji J. Macromol Rapid Commun. 2014; 35:1372-1378. [PubMed: 24849874]

96. Pasparakis G, Manouras T, Vamvakaki M, Argitis P. Nat Commun. 2014; 5:3623. [PubMed: 24710504]

97. Yesilyurt V, Ramireddy R, Thayumanavan S. Angew Chem-Int Edit. 2011; 50:3038-3042.

98. Hu X, Tian J, Liu T, Zhang G, Liu S. Macromolecules. 2013; 46:6243-6256.

99. Li HJ, Wang HX, Sun CY, Du JZ, Wang J. RSC Adv. 2014; 4:1961-1964.

100. Lin QN, Bao CY, Yang YL, Liang QN, Zhang DS, Cheng SY, Zhu LY. Adv Mater. 2013; 25:1981-1986. [PubMed: 23401259]

101. Tong R, Hemmati HD, Langer R, Kohane DS. J Am Chem Soc. 2012; 134:8848-8855. [PubMed: 22385538]

102. Tong R, Chiang HH, Kohane DS. Proc Natl Acad Sci U S A. 2013; 110:19048-19053. [PubMed: 24191048]

103. Kotharangannagari VK, Sánchez-Ferrer A, Ruokolainen J, Mezzenga R. Macromolecules. 2011; 44:4569-4573.

104. Cao J, Huang S, Chen Y, Li S, Li X, Deng D, Qian Z, Tang L, Gu Y. Biomaterials. 2013; 34:6272-6283. [PubMed: 23721796]

105. Sun L, Yang Y, Dong CM, Wei Y. Small. 2011; 7:401-406. [PubMed: 21294270]

106. Sun L, Ma XF, Dong CM, Zhu BS, Zhu XY. Biomacromolecules. 2012; 13:3581-3591. [PubMed: 23017146] 
107. Sun L, Zhu B, Su Y, Dong CM. Polym Chem. 2014; 5:1605-1613.

108. Kumar S, Allard JF, Morris D, Dory YL, Lepage M, Zhao Y. J Mater Chem. 2012; 22:72527257.

109. Discher DE, Ahmed F. Annu Rev Biomed Eng. 2006; 8:323-341. [PubMed: 16834559]

110. Meng FH, Zhong ZY, Feijen J. Biomacromolecules. 2009; 10:197-209. [PubMed: 19123775]

111. Tong X, Wang G, Soldera A, Zhao Y. J Phys Chem B. 2005; 109:20281-20287. [PubMed: 16853623]

112. Cabane E, Malinova V, Meier W. Macromol Chem Phys. 2010; 211:1847-1856.

113. Katz JS, Zhong S, Ricart BG, Pochan DJ, Hammer DA, Burdick JA. J Am Chem Soc. 2010; 132:3654-3655. [PubMed: 20184323]

114. Cabane E, Malinova V, Menon S, Palivan CG, Meier W. Soft Matter. 2011; 7:9167-9176.

115. Wang XR, Liu GH, Hu JM, Zhang GY, Liu SY. Angew Chem-Int Edit. 2014; 53:3138-3142.

116. Liu GH, Wang XR, Hu JM, Zhang GY, Liu SY. J Am Chem Soc. 2014; 136:7492-7497. [PubMed: 24786176]

117. Chen HB, Xiao L, Anraku Y, Mi P, Liu XY, Cabral H, Inoue A, Nomoto T, Kishimura A, Nishiyama N, Kataoka K. J Am Chem Soc. 2014; 136:157-163. [PubMed: 24283288]

118. Hogset A, Prasmickaite L, Selbo PK, Hellum M, Engesaeter BO, Bonsted A, Berg K. Adv Drug Deliv Rev. 2004; 56:95-115. [PubMed: 14706447]

119. Nishiyama N, Iriyama A, Jang WD, Miyata K, Itaka K, Inoue Y, Takahashi H, Yanagi Y, Tamaki Y, Koyama H, Kataoka K. Nat Mater. 2005; 4:934-941. [PubMed: 16299510]

120. Jayakumar MKG, Bansal A, Huang K, Yao RS, Li BN, Zhang Y. ACS Nano. 2014; 8:48484858. [PubMed: 24730360]

121. Martens TF, Remaut K, Demeester J, De Smedt SC, Braeckmans K. Nano Today. 2014; 9:344364.

122. Kabanov AV, Vinogradov SV. Angew Chem-Int Edit. 2009; 48:5418-5429.

123. Patnaik S, Sharma AK, Garg BS, Gandhi RP, Gupta KC. Int J Pharm. 2007; 342:184-193. [PubMed: 17574354]

124. Azagarsamy MA, Alge DL, Radhakrishnan SJ, Tibbitt MW, Anseth KS. Biomacromolecules. 2012; 13:2219-2224. [PubMed: 22746981]

125. Wu W, Shen J, Banerjee P, Zhou S. Biomaterials. 2010; 31:7555-7566. [PubMed: 20643481]

126. Bédard MF, De Geest BG, Skirtach AG, Möhwald H, Sukhorukov GB. Adv Colloid Interface Sci. 2010; 158:2-14. [PubMed: 19720369]

127. Esser-Kahn AP, Odom Sa, Sottos NR, White SR, Moore JS. Macromolecules. 2011; 44:5539_ 5553.

128. Campardelli R, Della Porta G, Gomez L, Irusta S, Reverchon E, Santamaria J. J Mater Chem B. 2014; 2:409-417.

129. Shi D, Matsusaki M, Akashi M. J Control Release. 2011; 149:182-189. [PubMed: 20727923]

130. Shi D, Matsusaki M, Kaneko T, Akashi M. Macromolecules. 2008; 41:8167-8172.

131. Fomina N, McFearin C, Sermsakdi M, Edigin O, Almutairi A. J Am Chem Soc. 2010; 132:95409542. [PubMed: 20568765]

132. Fomina N, McFearin CL, Sermsakdi M, Morachis JM, Almutairi A. Macromolecules. 2011; 44:8590-8597. [PubMed: 22096258]

133. Wang Z, Wang P, Tang X. ChemPlusChem. 2013; 78:1273-1281.

134. Lv C, Wang Z, Wang P, Tang X. Langmuir. 2012; 28:9387-9394. [PubMed: 22646923]

135. Vallet-Regi M, Balas F, Arcos D. Angew Chem-Int Edit. 2007; 46:7548-7558.

136. Slowing, Vivero-Escoto JL, Wu CW, Lin VSY. Adv Drug Deliv Rev. 2008; 60:1278-1288. [PubMed: 18514969]

137. Chen Y, Chen HR, Shi JL. Adv Mater. 2013; 25:3144-3176. [PubMed: 23681931]

138. Yang PP, Gai SL, Lin J. Chem Soc Rev. 2012; 41:3679-3698. [PubMed: 22441299]

139. Colilla M, Gonzalez B, Vallet-Regi M. Biomater Sci. 2013; 1:114-134.

140. Nadrah P, Planinsek O, Gaberscek M. J Mater Sci. 2014; 49:481-495. 
141. Mal NK, Fujiwara M, Tanaka Y. Nature. 2003; 421:350-353. [PubMed: 12540896]

142. Mal NK, Fujiwara M, Tanaka Y, Taguchi T, Matsukata M. Chem Mat. 2003; 15:3385-3394.

143. Vivero-Escoto JL, Slowing, Wu CW, Lin VSY. J Am Chem Soc. 2009; 131:3462-3463. [PubMed: 19275256]

144. Yuan Q, Zhang YF, Chen T, Lu DQ, Zhao ZL, Zhang XB, Li ZX, Yan CH, Tan WH. ACS Nano. 2012; 6:6337-6344. [PubMed: 22670595]

145. Xing QJ, Li NJ, Chen DY, Sha WW, Jiao Y, Qi XX, Xu QF, Lu JM. J Mater Chem B. 2014; 2:1182-1189.

146. Yan H, Teh C, Sreejith S, Zhu LL, Kwok A, Fang WQ, Ma X, Nguyen KT, Korzh V, Zhao YL. Angew Chem-Int Edit. 2012; 51:8373-8377.

147. Angelos S, Choi E, Vogtle F, De Cola L, Zink JI. J Phys Chem C. 2007; 111:6589-6592.

148. Lu J, Choi E, Tamanoi F, Zink JI. Small. 2008; 4:421-426. [PubMed: 18383576]

149. Croissant J, Maynadier M, Gallud A, Peindy N'Dongo H, Nyalosaso JL, Derrien G, Charnay C, Durand J-O, Raehm L, Serein-Spirau F, Cheminet N, Jarrosson T, Mongin O, Blanchard-Desce M, Gary-Bobo M, Garcia M, Lu J, Tamanoi F, Tarn D, Guardado-Alvarez TM, Zink JI. Angew Chem-Int Edit. 2013; 52:13813-13817.

150. Lin QN, Huang Q, Li CY, Bao CY, Liu ZZ, Li FY, Zhu LY. J Am Chem Soc. 2010; 132:1064510647. [PubMed: 20681684]

151. Wu CL, Chen C, Lai JP, Chen JB, Mu X, Zheng JS, Zhao YB. Chem Commun. 2008:2662-2664.

152. Li X, Zhang F, Zhao D. Nano Today. 2013; 8:643-676.

153. Yang D, Ma Pa, Hou Z, Cheng Z, Li C, Lin J. Chem Soc Rev. 2014; 44:1416-1448. [PubMed: 24988288]

154. Auzel F. Chem Rev. 2003; 104:139-174. [PubMed: 14719973]

155. Liu Q, Feng W, Li FY. Coord Chem Rev. 2014; 273:100-110.

156. Park YI, Lee KT, Suh YD, Hyeon T. Chem Soc Rev. 2014; 44:1302-1317. [PubMed: 25042637]

157. Idris NM, Jayakumar MKG, Bansal A, Zhang Y. Chem Soc Rev. 2014; 44:1449-1478. [PubMed: 24969662]

158. Carling CJ, Nourmohammadian F, Boyer JC, Branda NR. Angew Chem-Int Edit. 2010; 49:37823785 .

159. Yan B, Boyer JC, Branda NR, Zhao Y. J Am Chem Soc. 2011; 133:19714-19717. [PubMed: 22082025]

160. Fedoryshin LL, Tavares AJ, Petryayeva E, Doughan S, Krull UJ. ACS Appl Mater Interfaces. 2014; 6:13600-13606. [PubMed: 25090028]

161. Dai Y, Xiao H, Liu J, Yuan Q, Ma Pa, Yang D, Li C, Cheng Z, Hou Z, Yang P, Lin J. J Am Chem Soc. 2013; 135:18920-18929. [PubMed: 24279316]

162. Min YZ, Li JM, Liu F, Yeow EKL, Xing BG. Angew Chem-Int Edit. 2014; 53:1012-1016.

163. Liu J, Bu W, Pan L, Shi J. Angew Chem-Int Edit. 2013; 52:4375-4379.

164. Zhou L, Chen ZW, Dong K, Yin ML, Ren JS, Qu XG. Adv Mater. 2014; 26:2424-2430. [PubMed: 24347375]

165. Yang YM, Liu F, Liu XG, Xing BG. Nanoscale. 2013; 5:231-238. [PubMed: 23154830]

166. Yang Y, Velmurugan B, Liu X, Xing B. Small. 2013; 9:2937-2944. [PubMed: 23554151]

167. Viger ML, Grossman M, Fomina N, Almutairi A. Adv Mater. 2013; 25:3733-3738. [PubMed: 23722298]

168. Zhang R, Yao R, Ding B, Shen Y, Shui S, Wang L, Li Y, Yang X, Tao W. Adv Mater Sci Eng. 2014; 2014:1-9.

169. Zhao L, Peng J, Huang Q, Li C, Chen M, Sun Y, Lin Q, Zhu L, Li F. Adv Funct Mater. 2014; 24:363-371.

170. Gnach A, Lipinski T, Bednarkiewicz A, Rybka J, Capobianco JA. Chem Soc Rev. 2015; 44:1561-1584. [PubMed: 25176037]

171. Sun Y, Feng W, Yang P, Huang C, Li F. Chem Soc Rev. 2015; 44:1509-1525. [PubMed: 25113504] 
172. Shen J, Chen G, Vu AM, Fan W, Bilsel OS, Chang CC, Han G. Adv Opt Mater. 2013; 1:644650.

173. Xie X, Gao N, Deng R, Sun Q, Xu QH, Liu X. J Am Chem Soc. 2013; 135:12608-12611. [PubMed: 23947580]

174. Wen H, Zhu H, Chen X, Hung TF, Wang B, Zhu G, Yu SF, Wang F. Angew Chem-Int Edit. 2013; 52:13419-13423.

175. Dvir T, Banghart MR, Timko BP, Langer R, Kohane DS. Nano Lett. 2010; 10:250-254. [PubMed: 19904979]

176. Shamay Y, Adar L, Ashkenasy G, David A. Biomaterials. 2011; 32:1377-1386. [PubMed: 21074848]

177. Fan N-C, Cheng F-Y, Ho J-aA, Yeh C-S. Angew Chem-Int Edit. 2012; 51:8806-8810.

178. Chien YH, Chou YL, Wang SW, Hung ST, Liau MC, Chao YJ, Su CH, Yeh CS. ACS Nano. 2013; 7:8516-8528. [PubMed: 24070408]

179. Hansen MB, van Gaal E, Minten I, Storm G, van Hest JCM, Lowik D. J Control Release. 2012; 164:87-94. [PubMed: 23085152]

180. Yuan ZF, Zhao D, Yi XQ, Zhuo RX, Li F. Adv Funct Mater. 2014; 24:1799-1807.

181. Barhoumi A, Wang W, Zurakowski D, Langer RS, Kohane DS. Nano Lett. 2014; 14:3697-3701. [PubMed: 24884872]

182. Ayala-Orozco C, Urban C, Bishnoi S, Urban A, Charron H, Mitchell T, Shea M, Nanda S, Schiff R, Halas N, Joshi A. J Control Release. 2014; 191:90-97. [PubMed: 25051221]

183. Angelos S, Yang YW, Khashab NM, Stoddart JF, Zink JI. J Am Chem Soc. 2009; 131:1134411346. [PubMed: 19624127]

184. Wang X, Jiang G, Li X, Tang B, Wei Z, Mai C. Polym Chem. 2013; 4:4574-4577.

185. Bertrand O, Fustin CA, Gohy JF. ACS Macro Lett. 2012; 1:949-953.

186. Huang Q, Liu T, Bao C, Lin Q, Ma M, Zhu L. J Mater Chem B. 2014; 2:3333-3339.

187. Liao L, Liu J, Dreaden EC, Morton SW, Shopsowitz KE, Hammond PT, Johnson JA. J Am Chem Soc. 2014; 136:5896-5899. [PubMed: 24724706]

188. Azagarsamy MA, Anseth KS. Angew Chem-Int Edit. 2013; 52:13803-13807.

189. Yelin D, Rizvi I, White WM, Motz JT, Hasan T, Bouma BE, Tearney GJ. Nature. 2006; 443:765765. [PubMed: 17051200]

190. Kohane DS, Langer R. Chem Sci. 2010; 1:441-446.

\section{Biographies}

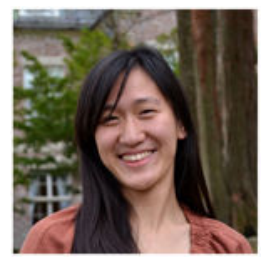

Alina Y. Rwei completed her B.S. in Chemical-Biological Engineering at the Massachusetts Institute of Technology (MIT). She is currently a Ph.D. student in the Department of Materials Science and Engineering and the Program of Polymers and Soft Materials at MIT under the supervision of Professor Robert Langer and Professor Daniel Kohane. She is the recipient of the 2014-2015 Chyn Duog Shiah Memorial Fellowship given by the MIT Office of the Dean for Graduate Education. Her current research focus is on light-triggered drug delivery. 


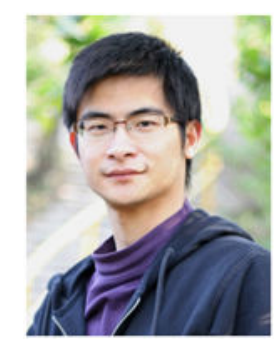

Weiping Wang received his Ph.D. from the Hong Kong University of Science and Technology (HKUST) under the supervision of Professor Ying Chau. He focused on the construction of self-assembled peptide nanoparticles as drug carriers. He is currently a postdoctoral associate under the supervision of Professor Robert Langer (MIT) and Professor Daniel Kohane (Boston Children's Hospital, HMS). His research interests include photo-stimulated drug delivery.

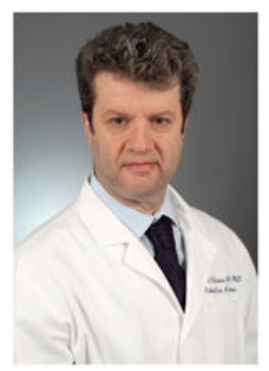

Daniel S. Kohane obtained his M.D. and a Ph.D. in Physiology from Boston University. He is a pediatrician, anesthesiologist, and pediatric intensive care physician. His laboratory at Boston Children's Hospital at Harvard Medical School focuses on biomaterials, drug delivery, and nanoscience, with a special interest in targeted and triggered drug delivery systems. 


\section{Highlights}

- Introducing photoactivation mechanisms based on energy conversion processes (i.e. photochemical, photothermal, photosensitization, upconversion processes).

- Providing examples of phototriggerable nanoparticles and emphasizing in vitro and in vivo drug delivery studies.

- Highlighting characteristics and considerations of phototriggered drug delivery systems in clinical applications (i.e. light penetration through tissue and phototoxicity). 


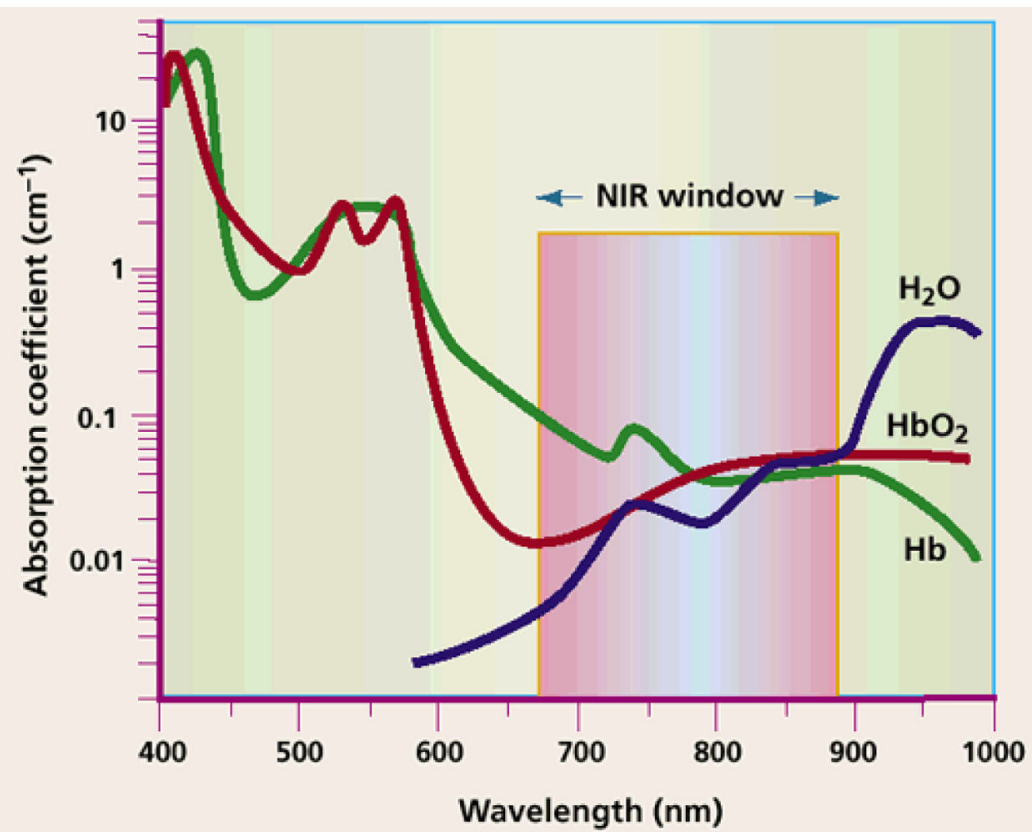

Figure 1.

Absorption spectra of the main chromophores in human tissue. The NIR window is bracketed by light absorption by hemoglobin $(<650 \mathrm{~nm})$ and water $(>900 \mathrm{~nm})$. Reprinted by permission from Macmillan Publishers Ltd: Nature Biotechnology [29], copyright 2001. 

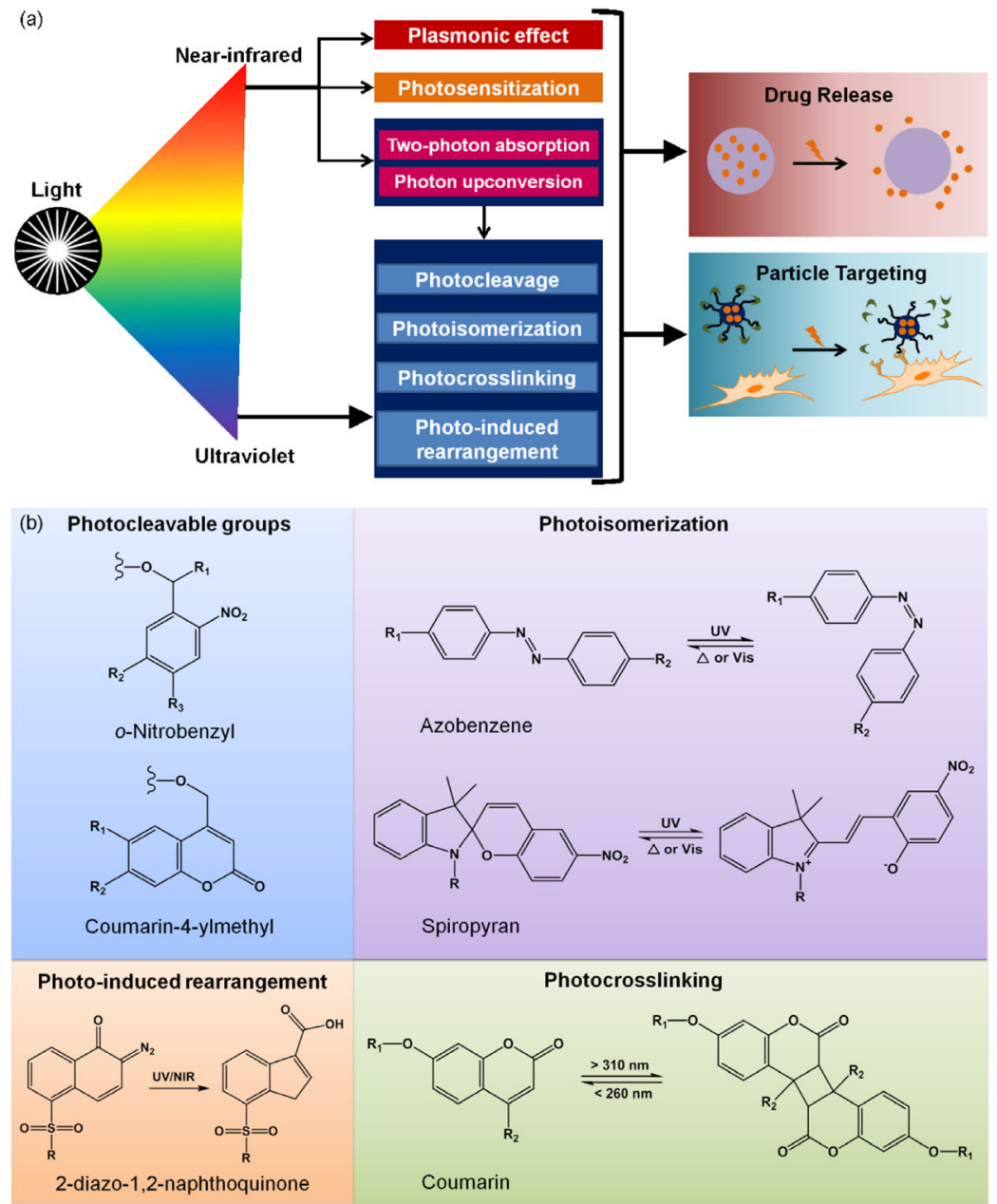

Figure 2.

Mechanisms for phototriggered drug delivery. a) Mechanisms of photoresponsiveness for nanoparticle targeting and drug release. b) Selected chemical groups used for photochemical reactions, such as photocleavage, photoisomerization, photo-induced rearrangement and photocrosslinking. 

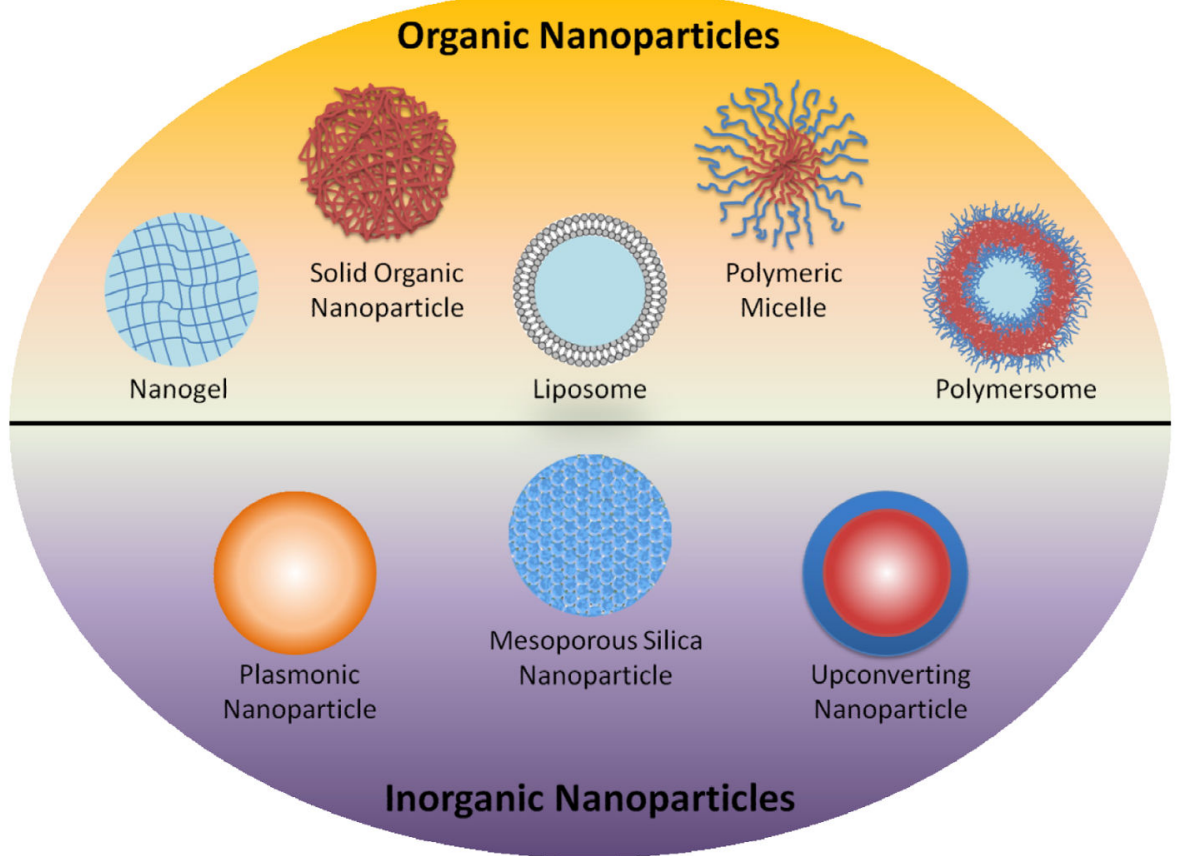

Figure 3.

Schematic of some organic and inorganic nanoparticles that have been developed as photoresponsive drug vehicles 


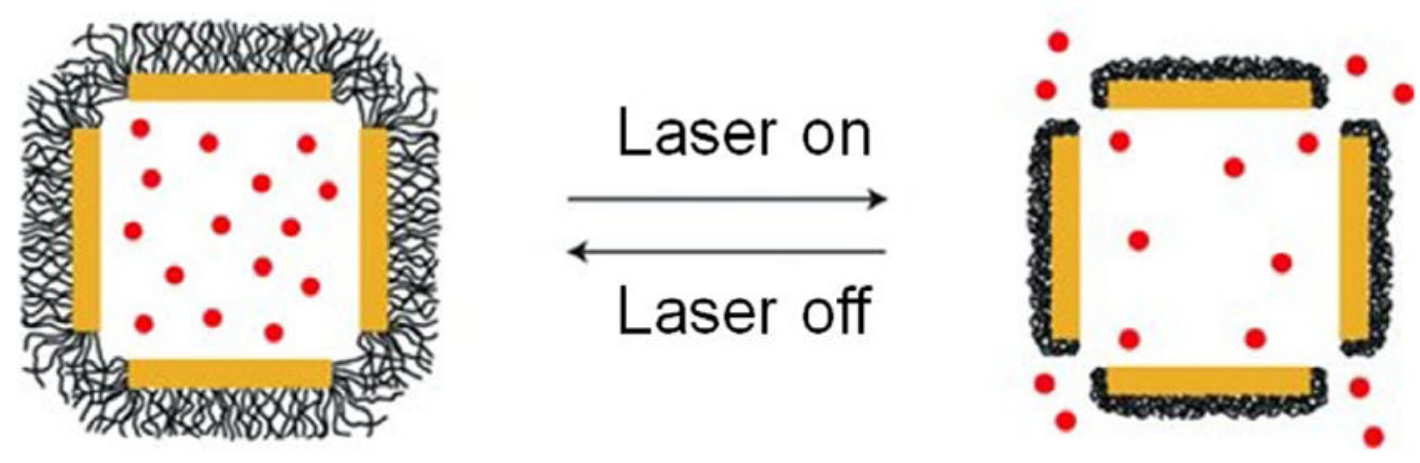

\section{$\sim$ Thermo-sensitive polymer} - Drug

Figure 4.

Photoresponsive gold nanocage. Upon exposure to NIR light, optical energy is converted to heat by the gold nanocage, inducing the collapse of the thermo-responsive polymers the opening of the pores, and the release of encapsulated cargo. When light is turned off, the system cools down to physiological temperature, at which the polymers revert back to their original extended conformation and drug release ceases. Reprinted by permission from Macmillan Publishers Ltd: Nature Materials [65], copyright 2009. 


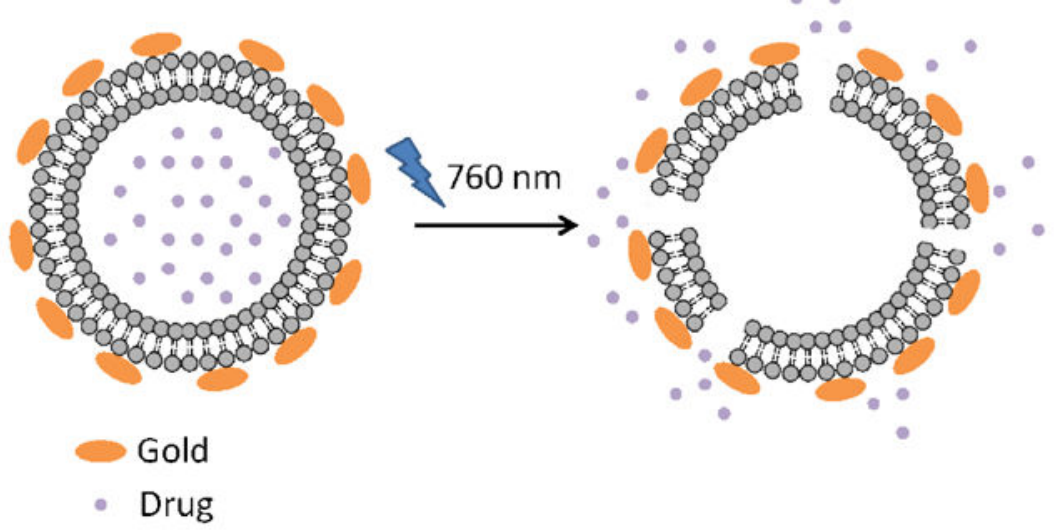

Figure 5.

Light-triggered release from a thermoresponsive liposome coated with gold nanoparticles. Upon irradiation with $760 \mathrm{~nm}$ light, the plasmonic photothermal effect induces local heating, which releases encapsulated cargo from the liposome. Adapted with permission from [88]. Copyright 2012 American Chemical Society. 


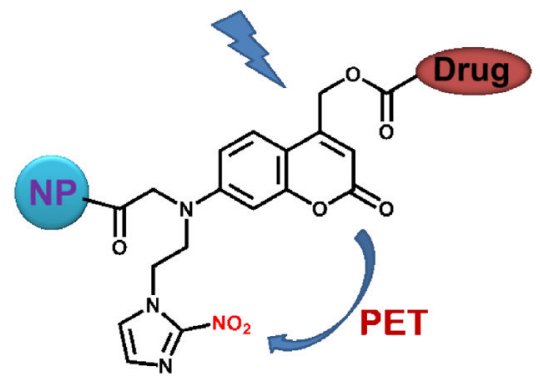

Normal conditions

No photocleavage

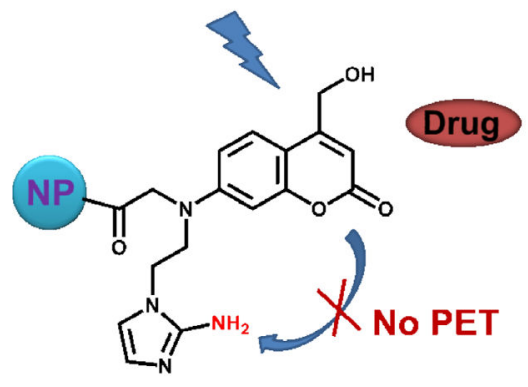

Hypoxia

Figure 6.

Hypoxia-activated phototriggered release of drugs in tumors. NP $=$ nanoparticle. $\mathrm{PET}=$ photoinduced electron transfer. Adapted with permission from [100]. Copyright 2015 John Wiley and Sons. 

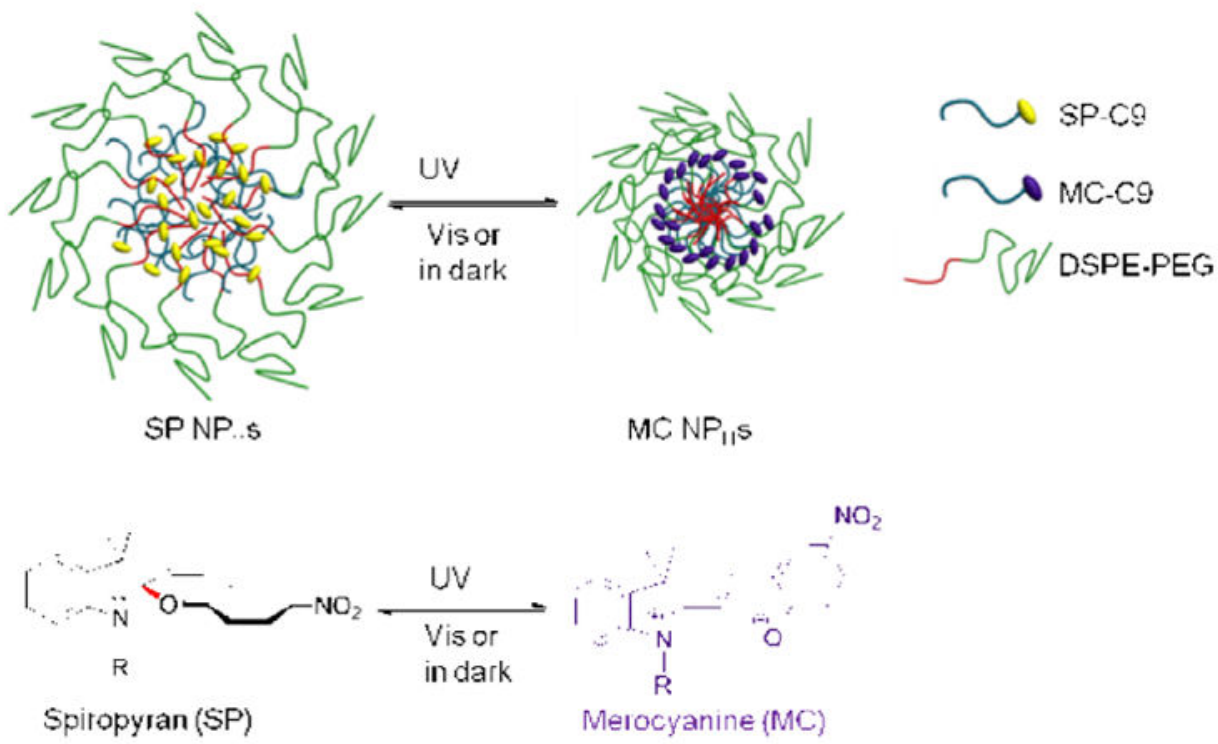

Figure 7.

Spiropyran-based photoswitchable nanoparticle (NP). Upon UV irradiation, the hydrophobic alkyl-spiropyran (SP-C9) molecules are isomerized to charged alkyl merocyanine (MC-C9) and the nanoparticle shrinks. The reaction reverses in darkness or after irradiation with visible light (500 nm - $600 \mathrm{~nm}$ ). Reprinted with permission from [101]. Copyright 2012 American Chemical Society. 
(a)

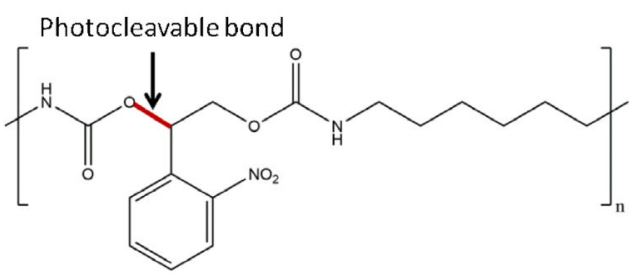

(b)
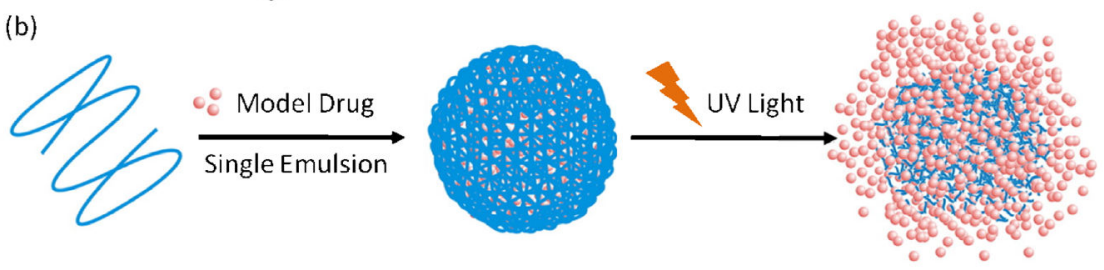

Figure 8.

Photodegradable polyurethane nanoparticle. a) Structure of a photolabile polyurethane; b) A hydrophobic model drug and photolabile polyurethane self-assemble into a drug-loaded nanoparticle. Upon UV irradiation, the polymer backbones degrade, releasing the encapsulated drug. Adapted with permission from [134]. Copyright 2012 American Chemical Society. 

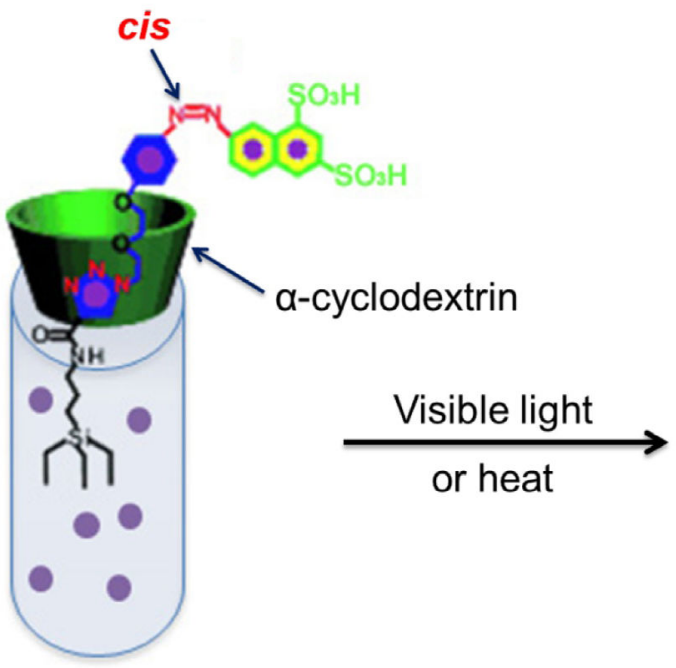

Blocked pore

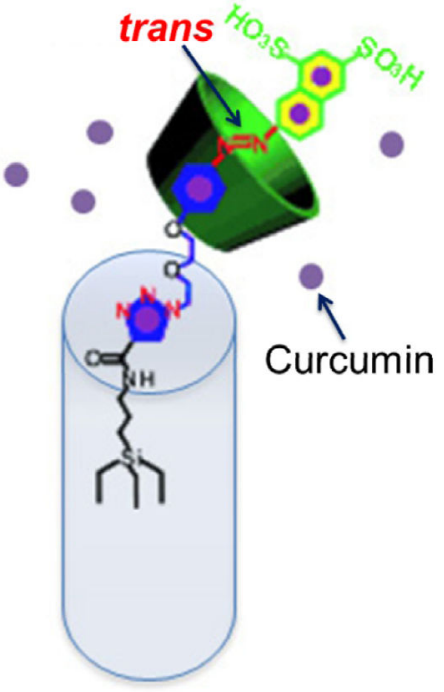

Unblocked pore

Figure 9.

Schematic representation of a single MSNP pore reversibly blocked by a photoresponsive [2]rotaxane containing an a-CD ring and an azobenzene-contained axle. Adapted with permission from [146]. Copyright 2012 John Wiley and Sons. 


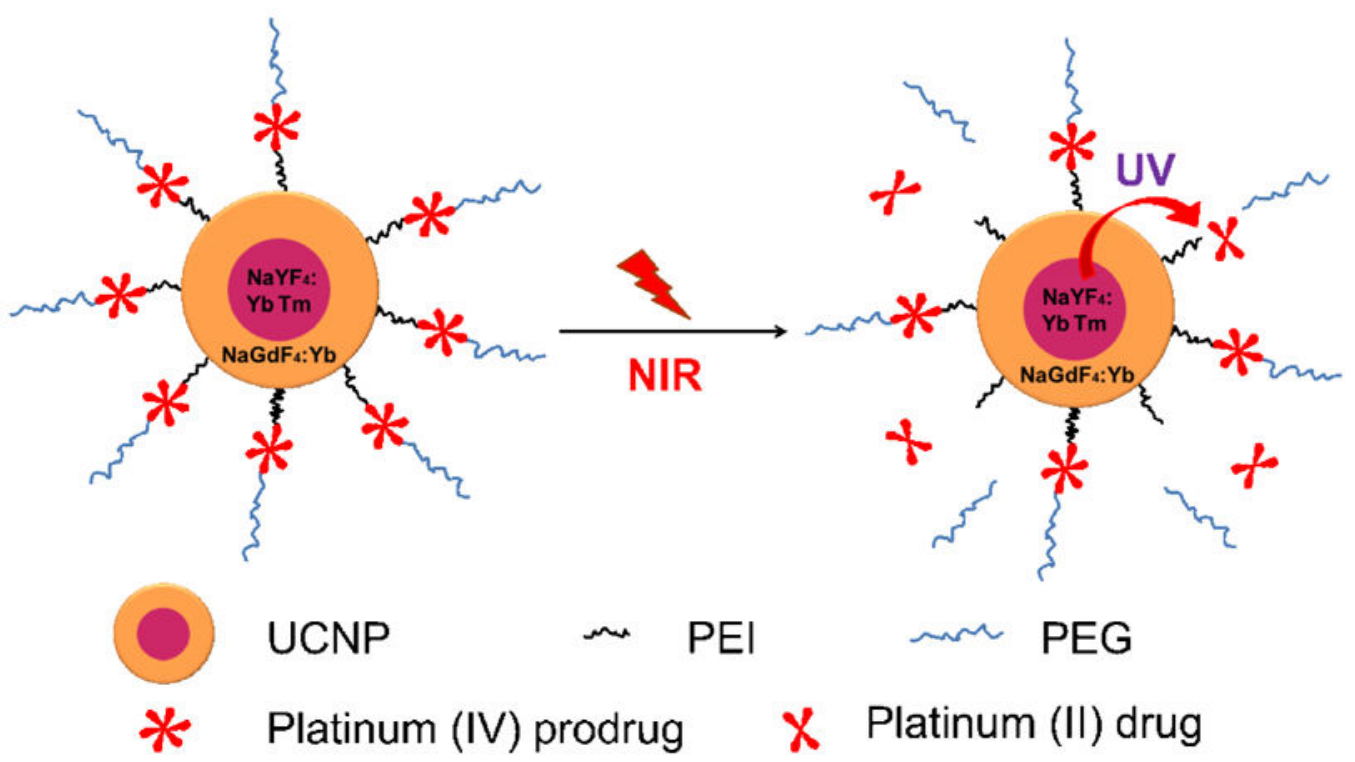

Figure 10.

Schematic illustration of a UCNP conjugated with the prodrug trans-platinum (IV), which becomes active platinum (II) and is cleaved from the nanoparticle by the upconverted UV light. UCNP = upconverting nanoparticle. $\mathrm{PEI}=$ polyethylenimine. $\mathrm{PEG}=$ poly $($ ethylene glycol). Adapted with permission from [161]. Copyright 2013 American Chemical Society. 


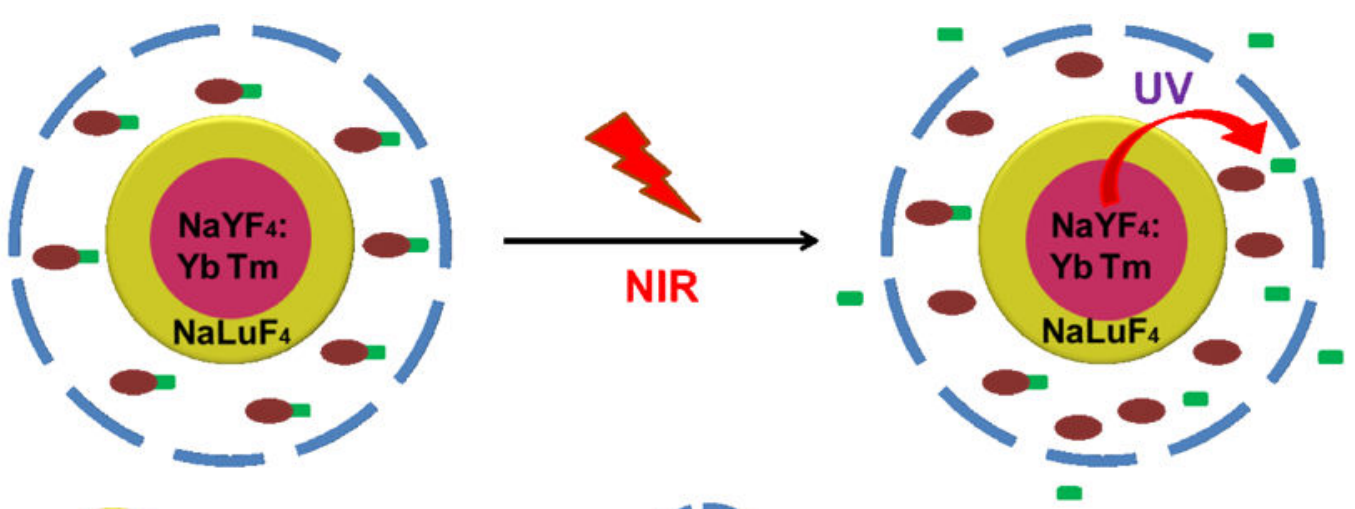

UCNP
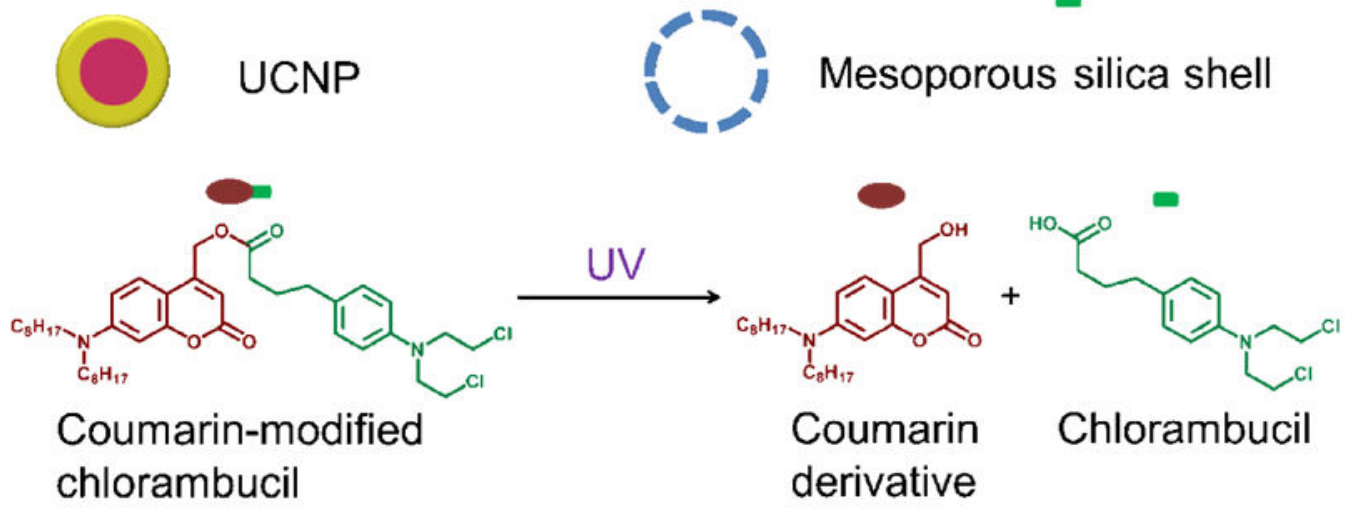

Figure 11.

Schematic illustration of a NIR-triggered UCNP-based drug delivery system. Photolysis of the hydrophobic prodrug by converted UV light generates the more hydrophilic drug chlorambucil, which is released. UCNP = upconverting nanoparticle. Adapted with permission from [169]. Copyright 2014 John Wiley and Sons. 


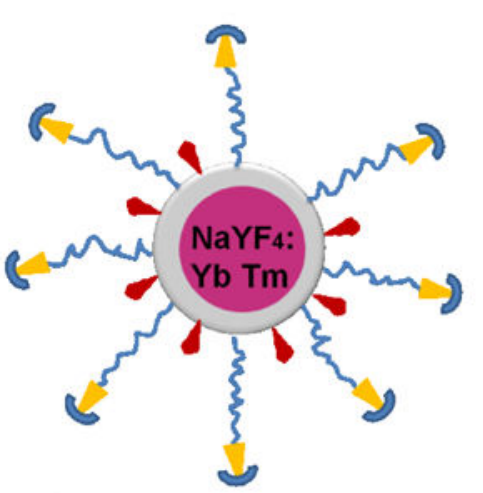

UCNP@SiO2

- Folic acid

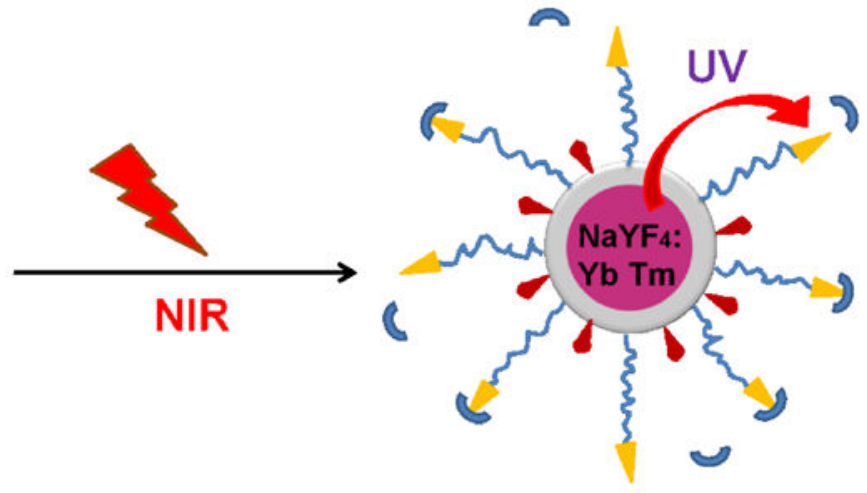

nus PEG

\section{2-nitrobenzyl cage group}

Figure 12.

Phototargeted UCNP-based nanocarrier. The UCNP can convert NIR light to UV light, removing the cage group and activating the cell binding function of folic acid. UCNP = upconverting nanoparticle. $\mathrm{PEG}=$ poly (ethylene glycol). Adapted with permission from [178]. Copyright 2013 American Chemical Society. 